\title{
DIPLOMACY AND PEAGE IN FRAGILE CONTEXTS
}

Erik Forsberg and Jonathan Marley

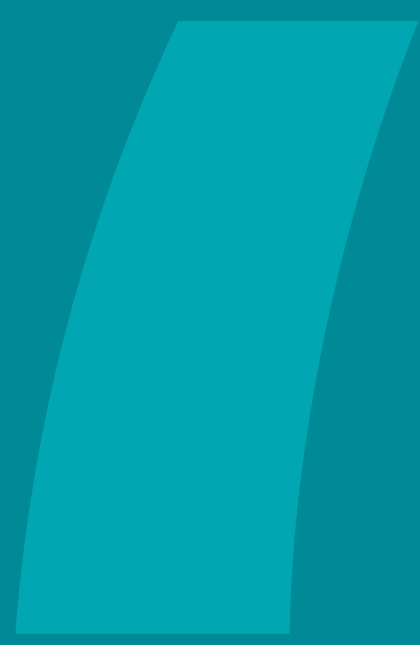

OECD DEVELOPMENT CO-OPERATION WORKING PAPER 77

Authorised for publication by Jorge Moreira da Silva, Director, Development Co-operation Directorate 



\section{Working Paper}

OECD Working Papers do not represent the official views of the OECD or of its member countries. The opinions expressed and arguments employed are those of the authors. Working Papers describe preliminary results or research in progress by the authors and are published to stimulate discussion on a broad range of issues on which the OECD works. Comments on the present Working Paper are welcomed and may be sent to dac.contact@oecd.org — the Development Co-operation Directorate, OECD, 2 rue André Pascal, 75775 Paris Cedex 16, France.

This document, as well as any data and any map included herein, are without prejudice to the status of or sovereignty over any territory, to the delimitation of international frontiers and boundaries and to the name of any territory, city or area.

Please cite this paper as Forsberg, E. and J. Marley, "Diplomacy and peace in fragile contexts", OECD Development Co-operation Working Papers, No 77, OECD Publishing, Paris. 


\section{Abstract}

Diplomats and other diplomatic actors serve as the primary political actors in fragile contexts, both for OECD Development Assistance Committee members and the broader international community. They directly contribute to immediate and long-term peace, and their broad political network and knowledge positions them as a nodal point for effective and inclusive humanitarian, development and peace action in fragile contexts. This paper examines three different functions diplomatic actors assume that contribute to peace in fragile contexts: diplomacy as global governance, diplomats as peacebuilders and diplomats as facilitators. This paper is one of ten working papers supporting States of Fragility 2020. It works together with Security actors in fragile contexts, Conflict prevention in fragile contexts, and Peacebuilding in fragile contexts to provide comprehensive background to Chapter 2 on peace in States of Fragility 2020. 


\section{Acknowledgements}

This paper was written by Erik Forsberg, Junior Policy Analyst, and Jonathan Marley, Policy Analyst, both at the Global Partnerships and Policies Division of the Development Co-operation Directorate of the OECD. The paper draws on input and insights from Development Assistance Committee (DAC) members and officials at a number of multilateral and non-governmental organisations, academia, and existing literature and case studies. It was prepared under the oversight of Paloma Durán y Lalaguna, Head of Division, and Cyprien Fabre, Acting Team Leader for Crises and Fragility at the Global Partnerships and Policies Division.

The paper has received valuable input from members of the Crises and Fragility team of the Global Policies and Partnerships Division. It was kindly peer reviewed by Marina Caparini from the Stockholm International Peace Research Institute and Dr Jennifer Cassidy of the University of Oxford. The paper has been edited by David McDonald.

The authors would like to thank those who supported the work by generously sharing their insights and experiences through interviews and meetings. They include members of the International Network on Conflict and Fragility (INCAF), officials from multilateral agencies, bilateral donors, civil society organisations, researchers and the members of the States of Fragility 2020 reference group. 


\section{Table of contents}

$\begin{array}{ll}\text { Abstract } & 4\end{array}$

$\begin{array}{ll}\text { Acknowledgements } & 5\end{array}$

Abbreviations and acronyms $\quad 8$

Executive summary 9

1 Diplomacy, peace and fragility 12

What is diplomacy? 12

Why does diplomacy in fragile contexts matter to DAC members? 16

Challenges to diplomacy are undermining the international community's ability to support peace

in fragile contexts 19

2 Diplomacy as global governance $\quad 21$

What does the global governance system look like? $\quad 21$

How does global governance affect the ability to make peace on the ground? 23

3 Diplomats as peacebuilders 28

Political action and dialogue $\quad 28$

Third-party diplomacy: The diplomacy of peacemaking 32

4 Diplomats as enablers, leaders and communicators 37

How can diplomatic actors influence responses to fragility in fragile contexts?

Forms of diplomatic leadership in fragile contexts 38

$\begin{array}{ll}\text { Diplomats as communicators and enablers } & 40\end{array}$

References $\quad 43$

Annex A. List of multilateral political missions in 2020

Notes $\quad 52$

Figures

Figure 1.1. DAC member embassies in fragile contexts by context and DAC member, 2019

Figure 3.1. Multilateral political missions by region and organisation, $2020 \quad 29$ 


\section{Boxes}

Box 2.1. The African Peace and Security Architecture: From peaceful contexts to a peaceful continent Box 2.2. COVID-19 and the call for a global ceasefire

Box 3.1. Supporting the fight against corruption and impunity in Honduras

Box 3.2. Equal and meaningful participation of women in conflict prevention and peacebuilding 


\section{Abbreviations and acronyms}

ACLED Armed Conflict Location \& Event Data Project

AMISOM African Union Mission to Somalia

APSA African Peace and Security Architecture

$A U$

African Union

DAC

Development Assistance Committee

ECOWAS Economic Community of West African States

EEAS European External Action Committee

HDP Humanitarian Development Peace

ICC International Criminal Court

ICG International Contact Group

ICJ International Court of Justice

IcSP Instrument contributing to Stability and Peace

MINUSCA UN Multidimensional Integrated Stabilization Mission in the Central African Republic

MINUSMA UN Multidimensional Integrated Stabilization Mission in Mali

MONUSCO UN Stabilization Mission in the Democratic Republic of the Congo

OAU Organization of African Unity

OECD Organisation for Economic Co-operation and Development

OSCE Organization for Security and Co-operation in Europe

PSC AU Peace and Security Council

REC Regional Economic Communities

UNAMID African Union - United Nations Hybrid Operation in Darfur

UNMISS United Nations Mission in South Sudan

WPS Women, peace and security 


\section{Executive summary}

Diplomatic actors are equipped with tools and skills to assume various roles in the international community's efforts to support peace and security in fragile contexts. They negotiate the normative and legal frameworks that govern peace and security engagement, as well as interventions and mediation before, during and post armed conflict. They frequently facilitate effective humanitarian, development and peace efforts by assuming leadership positions, enabling networks and applying local and specialist knowledge. This paper explores the influence and importance of diplomatic activity at multiple levels for addressing issues of conflict and fragility in fragile contexts.

\section{Diplomacy for peace at a global level}

\section{Diplomats and other peace actors need to adapt and be agile to operate efficiently in the global governance system}

One of the primary functions of diplomacy is to maintain the global governance system. From the UN Security Council to the governing bodies of different regional organisations and other multi-stakeholder fora for diplomacy, diplomats co-ordinate collective action at the global and regional levels to address transnational challenges, including international peace and security in particular. This function of diplomacy is essential to effectively address global public "bads", such as fragility, armed conflict, and insecurity. It contributes predictability, stability, and order to international community responses tackling issues of conflict and fragility. However, when international co-operation is lacking, the ability to support peace, development and humanitarian assistance on the ground is constrained. As tensions in global international co-operation increase, there is an increased need to be creative and adaptive in efforts to craft consensus and navigate diplomatic pathways to agreement on peace and security efforts in fragile contexts. Diplomats and other peace actors need to adapt and be agile, finding new avenues to shape effective interventions across the conflict cycle, where possible for the particular moment in time and issue at hand.

\section{Diplomacy for peace in fragile contexts}

\section{Diplomacy is at the core of efforts to support peace in fragile contexts}

Any efforts to broker and maintain international peace are based on co-operation and political processes - the core of diplomatic practice. Diplomats and diplomacy are therefore particularly well placed to take on the task to promote peace in fragile contexts. They possess a set of tools that can shift incentives away from armed conflict towards political solutions, and can promote institutions conducive for peace. 


\section{Development Assistance Committee members have an extensive network of diplomatic representation across fragile contexts}

OECD Development Assistance Committee (DAC) members have a strong diplomatic presence in fragile contexts, amounting to a total of 571 resident embassies and permanent delegations covering 56 of the 57 fragile contexts. In addition, 60 multilateral political missions are deployed around the world, 32 of which operate in contexts classified as fragile in the OECD fragility framework.

\section{Third-party diplomacy is often a vital enabler of peace and conflict prevention}

Mediation is the type of diplomacy most closely related to peacemaking and peacebuilding, and is a crucial instrument for peace. Of the 165 negotiated settlements reached in conflicts in fragile contexts between 1991 and 2017, only 19 were concluded without any involvement from a third-party mediator. The success rate of mediation varies significantly depending on the context, type of mediator and conflict dynamics, and reaching a politically negotiated peace agreement is only the first stage in a longer peace process. Nonetheless, mediation remains an essential, flexible and effective tool for peace.

Mediation should be seen as part of broader engagement to support peace. In many cases it is conducted in conjunction with military efforts to provide the stability and security needed for fruitful peace negotiations, as well as development programmes and peacebuilding initiatives to re-establish social capital, including inter-communal trust and reconciliation. Security actor operations, development co-operation, and peacebuilding efforts all have an impact on the dynamics of conflict and incentives for peace. Mediators use the leverage and dynamics of security and development engagement to craft peace agreements, and the implementation of such agreements requires sustained assistance, both financial and political. The actions and inaction of development, peacebuilding and security actors can help reinforce a mediated solution or undermine its success. It is therefore important to ensure the full range of support to peace is mobilised and coordinated, seizing the opportunities for sustained peace that mediators facilitate.

\section{Diplomats can ensure political factors are sufficiently addressed in efforts to prevent conflict and build peace}

The contributions of diplomatic actors to peace extend beyond negotiated settlements and conflict resolution. Their core strength and competency is continuous communication and dialogue. Through dialogue, diplomatic actors provide political assistance and pressure to address the political root causes of armed conflict and violence. There is great potential in collaborative and coherent developmentdiplomatic approaches, which make use of a variety of tools in combination to address key factors contributing to conflict and fragility. The multi-layered political knowledge of diplomatic actors and the political networks of which they are part can be leveraged to address political factors in development cooperation, peacebuilding, and conflict prevention efforts in fragile contexts - improving the chances that the results of such efforts will be sustained and transformative. Peacebuilding, conflict prevention, and development co-operation that lack a political lens and experience, risk becoming too process driven, without a sustainable theory of change that takes into account key political causes of armed conflict, violence, and fragility.

\section{Through leadership and political access, diplomats can enable and facilitate networks across the nexus in fragile contexts}

Diplomatic actors operating in fragile contexts have unique mobility to engage with actors across the triple nexus, including multiple official and non-official actors, political, security and business leaders, civil society and other individuals and groups. This access and appreciation for the local character of fragility, together with their official status - which combines legal authority, legitimacy, and power of influence - frequently places diplomats in positions to assume convening or facilitating roles that link national and international 
actors together on issues of fragility. Through their knowledge of political dynamics at different levels and access to multiple actors, bilateral and multilateral diplomatic actors can and do provide leadership across all pillars of engagement in fragile contexts. They are frequently best placed to be "nexus trilingual" with the ability to bring actors and partners together on a range of issues.

This function assumed by diplomats is critical to the implementation of the triple nexus - both to guarantee communication and awareness across the pillars of engagement in fragile contexts, and to ensure activities across the nexus are aligned with national priorities. The broad political network possessed by diplomats, which encompasses engaging with governments, opposition parties, civil society organisations and the plethora of external actors in fragile contexts, positions them as a nodal point for effective and inclusive humanitarian, development and peace actions.

\section{Diplomatic actors' access to new communications technologies shapes public and data diplomacy}

The basis of diplomatic convening power and leadership can be found in their knowledge, perspective and experience, as well as their relative capacity to influence, persuade and exert pressure for change in a fragile contexts. The proliferation of social media communications, including in fragile contexts, has transformed diplomatic practice for foreign ministries and diplomats. Critically analysing this space is vital for informing policy, particularly in extremely fragile or conflict-affected contexts, in order to gain an understanding of the aims, rhetoric, approaches and ideology of the various groups who apply digital means to influence local and international audiences. The ability of diplomatic missions to generate and redistribute data on issues of fragility holds great importance for generating evidence-based solutions to issues of fragility. 


\section{Diplomacy, peace and fragility}

This paper focuses on the roles of diplomatic actors at different levels and the ways in which they shape responses within fragile contexts. Diplomatic actors include: official state diplomats, diplomatic representatives of multilateral organisations, and non-official actors assuming diplomatic roles for various reasons depending on a context's dynamics - most often captured through track two and three diplomacy. The paper highlights three main functions fulfilled by diplomatic actors contributing to peace - shaping global governance, contributing to peacebuilding and conflict prevention, and facilitating effective responses to conflict by actors across the 'triple nexus'. This paper also acknowledges the impact of technology on diplomatic practice, especially for public and digital diplomacy. It focus in particular on the contribution of external diplomatic actors in and for fragile contexts, and not on diplomatic actors from fragile contexts, although the latter is an area worthy of further consideration.

\section{What is diplomacy?}

Diplomacy is a peaceful and continuous process of communication through which countries execute their foreign policy. It involves international relations among states or other collectives manifested through intermediation, reciprocity, and formal representation (United Nations, 1961 [1]). Diplomatic actors continuously adopt skills and properties that enable them to assume a variety of roles within international community efforts to support peace and security in fragile contexts. These include political access and networks, adaptability, and the ability to forge relationships (Spies, 2019[2]).

While members of the OECD Development Assistance Committee (DAC) broadly share a set of values, their individual foreign policies are not always completely aligned with peace and development objectives. For this reason, it is important to recognise and understand their roles and potential to influence peacebuilding and development, negotiate the normative and legal frameworks governing peace and security engagement, intervene and mediate in armed conflict, and facilitate effective humanitarian, development and peace efforts through political leadership, networks and knowledge. This paper explores the roles and functions that diplomatic actors assume to support peacebuilding and development cooperation in fragile contexts, and highlights some of the avenues for deepened and improved use of diplomatic tools in preventing conflict, sustaining peace, and addressing the root causes of fragility.

Contrary to what cynics allege, diplomats have a mandate that far exceeds the simple communication of preset messages. They have to bargain, "think out of the box", create common ground, add value and engineer peace where none exists. The work is never done: new fissures appear; new generations of politicians forget the lessons learnt. The profession's duty, and its strength, lies in its continuity of communication. After all, the world we live in is largely a product of diplomacy: the peace treaties, charters of international organisations, even the borders of sovereign states result from deals struck by diplomats. Diplomacy outlives empires and ideologies, trends and fads, and all the many ways we humans find to undermine each other (Spies, 2019[2]).

\section{Bilateral and multilateral diplomacy}

The two main types of official state-based diplomacy, or "track one" diplomacy, considered in this paper are bilateral diplomacy and multilateral diplomacy. Non-state actors, such as non-governmental organisations (NGOs) and private sector actors, can be involved in diplomacy through so-called "track 
two", "track three" and "multitrack" diplomacy (Mapendere, $2005_{[3]}$ ). These types of diplomacy operate at different levels, but each contributes to international efforts to support peace in fragile contexts, for example by mediating in conflicts and promoting important political reforms conducive to peace and resilience (Böhmelt, 2010[4]]). "Track three" diplomacy, or people-to-people diplomacy, works at the grassroots level to boost underlying societal dynamics that allow peace processes to take place. It has proved significant in some fragile contexts and is explored in the paper Peacebuilding in Fragile Contexts (Marley, 2020 ${ }_{[5]}$ ).

Diplomacy in fragile contexts is most often conducted through accredited bilateral representation. However, resident embassies are not the only channel for bilateral diplomacy. Non-resident ambassadors, diplomatic envoys, special political missions, and other permanent and ad-hoc modes of diplomacy are equally a part of the bilateral diplomatic toolbox (Spies, 2019 ${ }_{[2]}$. . As stated in the Vienna Convention on Diplomatic Relations - which is the core institutional framework for diplomacy - diplomacy's primary function is to serve the public interest of the sending state's citizens by executing its foreign policy (United Nations, 1961[1]).

While bilateral diplomacy constitutes the bedrock of diplomatic exchange between states, and has existed for several hundred years, multilateral diplomacy is a comparatively recent and fast-growing innovation. Global diplomatic activity has increased significantly over the last 100 years, with much of this increase attributable to the growth of diplomacy conducted simultaneously among three or more states or organisations (Spies, 2019 ${ }_{[2]}$ ). Such multilateral diplomacy involves parliamentary diplomacy, including through the United Nations (UN) General Assembly, the UN Security Council and the governing organs of various regional organisations. However, it is also conducted in more ad-hoc fora and at lower levels. Countries might form groups within multilateral diplomatic institutions or host-countries, such as the G77 coalition of developing countries in the United Nations. Furthermore, various groups of countries gather regularly at the highest level through groups for co-operation such as the G20, the G7 and the G7+ coalition of countries affected by conflict and fragility (Spies, 2019[2]). 


\section{DIPLOMACY IN FRAGILE CONTEXTS}

\section{DAC members have a strong diplomatic presence in fragile contexts}

In total, there are 571 DAC member embassies and permanent delegations covering 56 of the

57 fragile contexts
Multilateral and regional organisations maintain political missions around the world.

32 of 60 multilateral political missions operate in fragile contexts, providing political support to a total

\section{9 fragile contexts}

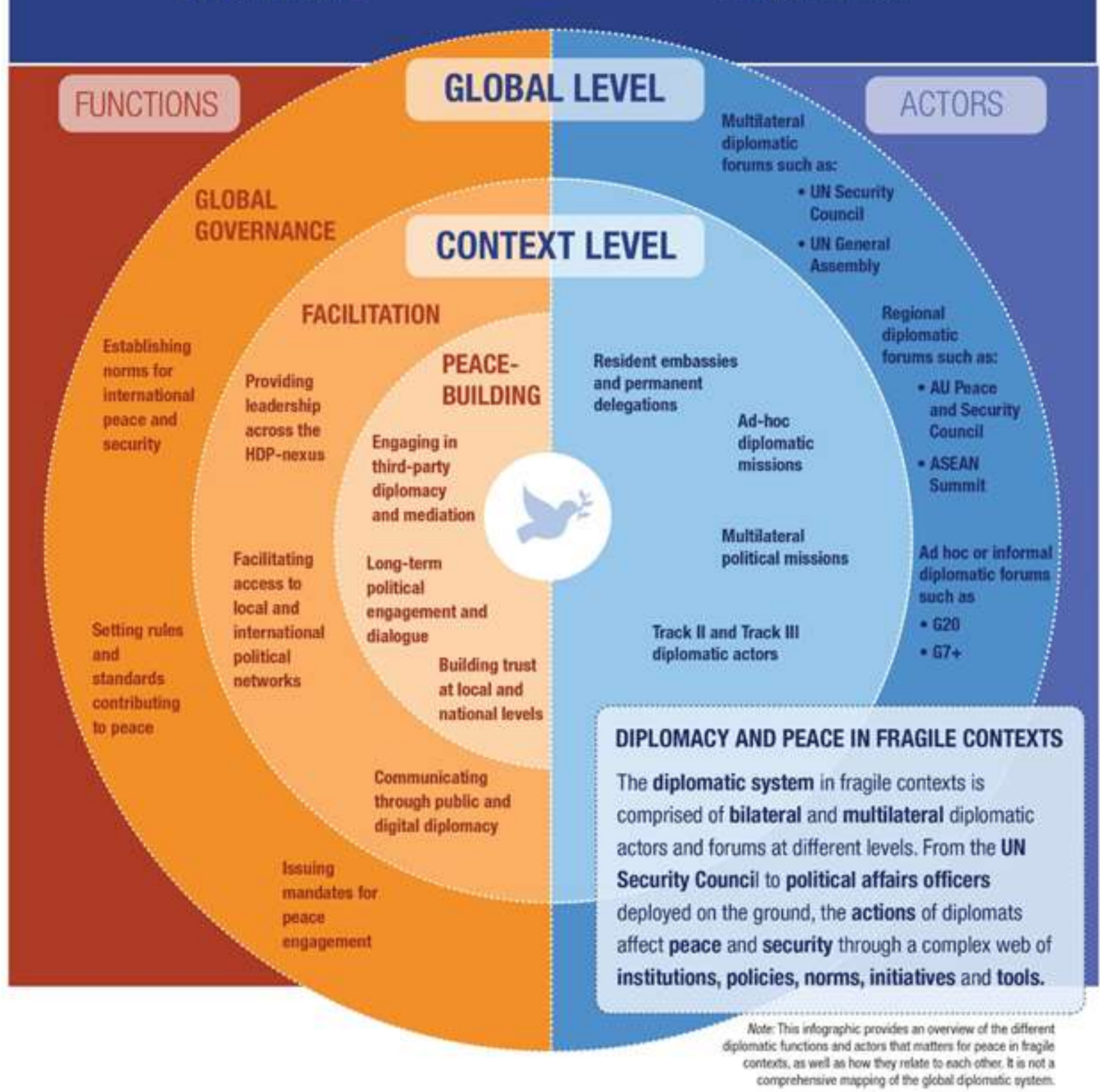

Note : This figure was prepared by the OECD based on information gathered in the process of writing this report 


\section{Diplomatic support to peace and development efforts}

The quest for global peace and security is a constant subtext in diplomatic practice. The modern multilateral system, which is anchored in the United Nations, was founded with the primary objective of "saving future generations from the scourge of war" (United Nations, $\left.1945_{[6]}\right)$. However, the role of diplomacy at the core of efforts to promote peace and security long predates the founding of the United Nations. Any efforts to broker and maintain international peace are based on co-operation and political process, the crux of diplomatic practice. Diplomatic actors and diplomacy are particularly well placed to take on the task of promoting peace, as diplomacy is based on intermediation with the objective to promote friendly relationships between actors. Furthermore, the tools at the disposal of diplomatic actors enable them to incentivise other state and non-state actors away from armed conflict and towards peaceful political solutions.

Diplomacy, particularly multilateral diplomacy, provides the international community with a means to achieve global governance of peace and security. Over the last century, a plethora of mechanisms, charters, institutions, and tools have been developed through multilateral diplomacy that are used to set norms, enforce rules, and respond to conflict in order to ensure peace and security across the (Global Challenges Foundation, $\left.2017_{[7]}\right)$. Perhaps the most prominent of these inventions is the Charter of the United Nations, which sets out a number of principles for the 193 member states to protect human rights, promote development, and ensure peace and security, and which has created tools and institutions to enforce these principles (United Nations, $\left.1945_{[6]}\right)$. Similarly, the African Union has established a set of norms and principles regarding governance, human rights, and peace and security, together with a set of tools and institutions to enforce those norms and standards (ACCORD, 2014[8]). The OECD DAC also functions as a diplomatic institution through which members jointly govern development co-operation practices and co-ordinate the voice of the donor community (OECD, 2017[9]).

Some of the tools and mechanisms developed and used by these bodies, such as peacekeeping, international courts, and different development efforts, do not form part of the diplomatic toolbox. However, their application is to a large extent the product of diplomacy, and their effective operation is contingent on functioning diplomatic relationships at the highest level. This function fulfilled by diplomatic actors is examined in Chapter 2.

Diplomatic actors also engage directly in peacebuilding activities in fragile contexts, bargaining for peace and promoting political peace processes in conflict-affected areas. In the context of the United Nations and the multilateral system at large, these mechanisms and tools fall primarily under Chapter VI "Pacific Settlement of Disputes" of the Charter of the United Nations, which states that "the parties to any dispute, the continuance of which is likely to endanger the maintenance of international peace and security, shall, first of all, seek a solution by negotiation, enquiry, mediation, conciliation, arbitration, judicial settlement, resort to regional agencies or arrangements, or other peaceful means of their own choice" (United Nations, $\left.1945_{[6]}\right)$. Diplomatic actors from multilateral and regional organisations, as well as states, may act as intermediaries in such dispute settlements, creating conditions for dialogue and peaceful political solutions to conflict where they are otherwise absent (Wallensteen and Svensson, 2014[10]).

The UN Secretary-General has traditionally served such a purpose, establishing good offices and mediating between parties to conflicts (United Nations, 2011 [11]). Several DAC members and regional organisations are also involved regularly in such third-party diplomacy activities (Spies, 2019 ${ }_{[2]}$ ). However, third-party diplomacy is not the only diplomatic tool used to promote international peace and security. DAC members and multilateral organisations also engage in long-term political dialogue, promoting political conditions conducive to sustained, positive peace and development. Such conditions may include promoting human rights, gender equality, democracy, and inclusive governance. These roles played by diplomatic actors from the international community are important to ending violence and armed conflict, as well as building positive peace through the creation of conditions fundamental to long-term, sustained 
peace and development (OECD, 2019 $\left.9_{[12]}\right)$. The peacebuilding functions fulfilled by diplomatic actors are examined further in Chapter 3.

A third function fulfilled by diplomatic actors in efforts to support peace, development and humanitarian assistance is providing leadership and political knowledge. All efforts to support peace and prevent conflict require politically informed decision-making and political leadership, fundamentally because all peace processes are political. Through the DAC Recommendation on the Humanitarian-Development-Peace Nexus, members of the DAC and multilateral partners have acknowledged the importance of political engagement and leadership for resolving violent conflicts through political agreements in the short term, and ensuring fair and inclusive political systems that deliver equitable development and lasting peace in the long term. The importance of ensuring humanitarian access through diplomatic efforts has also been recognised (OECD, 2019 $\left.9_{[12]}\right)$.

Diplomatic leadership and engagement take different forms and roles and occur at different levels with a variety of effects, some of which are examined further in Chapter 4. The work of diplomatic actors is vital for the composition of international trade agreements, treaties, and other agreements, such as the Paris Climate Change Agreement (2015), initiatives such as Agenda 2030 and Agenda 2063, and the evaluation and composition of UN Security Council mandates on issues ranging from UN Security Council Resolution 1325 on Women, Peace and Security to peacekeeping mandates. Diplomatic actors also provide the connective grey matter between different international and regional organisations and for international summits that are critical for sustained dialogue potentially enabling (and sometimes disabling) opportunities for collective responses to issues of fragility. They can also play an entrepreneurial role in reimaging and inventing formal and informal platforms to forge coalitions for specific issues. For example, the Contact Group for Kosovo provided the strategic framework that guided a multidimensional response encompassing humanitarian response, development, peace enforcement and peacebuilding (Forsberg, $2020[13])$.

\section{Why does diplomacy in fragile contexts matter to DAC members?}

\section{Diplomatic and development priorities overlap in fragile and conflict-affected contexts: using diplomacy to support peace is effective}

Efforts to address fragility constitute a global public good and are in the national public interest of DAC members. The recent paper Fragility and the SDGs (Marley and Desai, 2020[14]) argues that issues such as violence, terrorism, displacement and instability have increasingly shaped the foreign policies of DAC members over the last decades, and argues that addressing these global public "bads" requires action to address the root causes of fragility in the most fragile contexts. Fragility and Conflict (Desai, 2020[15]) and Fit for Fragility (Schreiber and Loudon, 2020[16]) take the argument further, examining approaches to improve conflict prevention and development co-operation in fragile contexts. Together, they make the case that addressing the root causes of fragility and preventing conflict must be a whole-of-government priority, for which development co-operation is an important tool. Mitigating violence, terrorism, displacement and instability are not only foreign policy objectives, but also development policy priorities for many DAC members. The need to address the root causes of fragility, prevent armed conflict and support sustained peace is therefore shared between development and diplomatic actors.

Foreign policy is driven by national interest which is not always aligned with development priorities and may differ among actors of the international community. Diverging foreign and security policy between stakeholders in the international community can fuel conflicts in fragile contexts. However, where these policies are aligned, the tools at the disposal of diplomatic actors are among the cheapest and most effective for identifying and addressing issues vital to achieving systemic improvements in fragility and 
ensuring sustained peace (Gates, 2020[17]). When diplomacy works, it can stop wars, reduce the need for expensive security operations, and improve the outcomes of development efforts.

The concept of the 3Ds was born out of the notion that priorities and responsibilities overlap between the diplomatic, defence, and development communities. The three pillars increasingly operate in conjunction in countries and regions marked by conflict and fragility (Cole, 2017 $[18]$ ). However, in too many cases, the pillars of engagement work in silos ill-adapted to achieve the complementarity and coherence needed to efficiently support contexts on their path from conflict to peace (Cole, 2017 $[18]$ ), and from fragility to resilience. Such lack of coherence decreases the ability of the international community to mitigate risks and enhance coping capacities to the benefit of fragile and non-fragile contexts alike (Desai and Forsberg, $2020[19])$.

\section{DAC members have an extensive diplomatic network in fragile contexts}

The diplomatic network in fragile contexts is extensive. DAC member states maintain bilateral diplomatic relations through resident embassies and permanent delegations ${ }^{1}$ with all but one fragile context. ${ }^{2}$ They $^{2}$ do so, to a relatively large extent, in areas where the security situation is highly unstable. In total, there are 571 DAC member embassies and delegations operating in fragile contexts (Lowy Institute, 2019 [20]; EEAS, $2020[21]$ ) (Figure 1.1). In two fragile contexts, the Comoros and Yemen, ${ }^{3}$ only one DAC member maintains an embassy or delegation (France and the European Union, respectively). In an additional two contexts, Lesotho and Syria, ${ }^{4}$ only two embassies or delegations are present. The only fragile context that does not host any DAC member embassy or delegation is the West Bank and Gaza Strip, although several consulates, political affairs offices and diplomatic representations oriented towards relations with Palestinian authorities operate in Bethlehem, Jerusalem and Ramallah. In five contexts, Ethiopia, the Islamic Republic of Iran, Kenya, Nigeria and Pakistan, there are more than 20 DAC embassies (Figure 1.1). The extremely fragile context with the largest number of DAC member embassies deployed is Iraq with 18 embassies, closely followed by Afghanistan and Democratic Republic of the Congo (DRC) with 17 and 16 respectively.

The DAC members with the largest number of resident embassies or delegations in fragile contexts are the United States (US), the European Union (EU), France, Germany, and the United Kingdom, all of whom have more than 40 embassies or delegations in fragile contexts (Figure 1.1).

DAC members are also among the most prominent contributors to multilateral, diplomatic, and political engagement in fragile contexts. There are 60 multilateral political missions ${ }^{5}$ deployed around the world, 32 of which are in fragile contexts (see Table A in Annex A), and a large proportion of which are funded by DAC members. For example, DAC members' total contribution to the UN budget amounts to more than two-thirds of the USD 3 billion UN budget for 2020 (United Nations, 2018[22]).

A significant amount of diplomatic capacity is thus deployed or supported by DAC members in fragile contexts, including in contexts ravaged by violence and armed conflict. DAC members are also engaged in these contexts through development, humanitarian, and other peace actors. In order to effectively address the root causes of fragility and encourage fragile contexts on their path towards resilience, there must be coherence and complementarity between these pillars of engagement (OECD, 2019 $\left.{ }_{[12]}\right)$. 
Figure 1.1. DAC member embassies in fragile contexts by context and DAC member, 2019

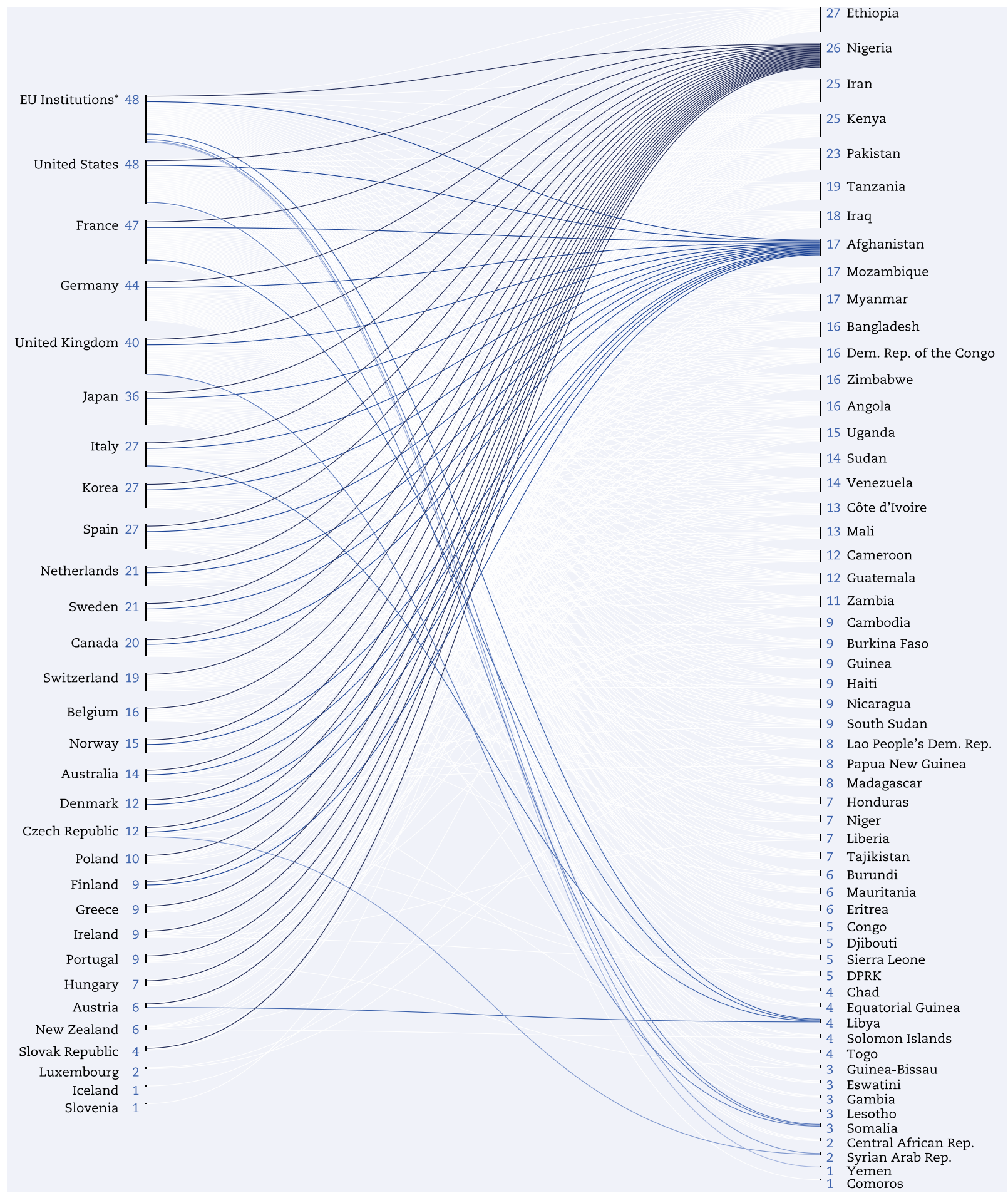

Notes: Numbers in blue refer to the number of embassies or delegations each DAC member deploys and that are present in each fragile context. The six fragile contexts that are highlighted are those that experienced high-intensity conflict in 2019. General consulates, political missions and other types of diplomatic missions that are not embassies or permanent delegations are excluded. DPRK refers to Democratic People's Republic of Korea.

${ }^{*} E U$ Institutions deploy delegations rather than embassies. The EU institutions delegations to Syria and Yemen are currently temporarily relocated to Beirut and Amman, respectively.

Sources: Data sourced from the Lowy Institute $\left(2019_{[20]}\right)$, Global Diplomacy Index, https://globaldiplomacyindex.lowyinstitute.org/ and the European Union (2020[21]), EU in the World (webpage), https://eeas.europa.eu/headquarters/headquarters-homepage/area/geo en. 


\section{Challenges to diplomacy are undermining the international community's ability to support peace in fragile contexts}

Since end of the 20th century, global diplomacy has faced a series of challenges and threats. In some countries, military and other security actors have been accused of crowding out diplomatic capacity and status in issues of foreign policy. In other contexts, rising concerns about the cost of maintaining resident embassies and other permanent bilateral diplomatic channels (Spies, 2019 ${ }_{[2]}$ ) have led to cutbacks in diplomatic capacity, particularly in high-cost locations such as fragile contexts. Lately, the multilateral system has faced significant challenges and pressure, as a result of a lack of confidence in multilateral institutions such as the UN, as well as growing disunity among important stakeholders in the global multilateral system (Lupel, 2019[23]). If these trends continue, they risk undermining the international community's ability to support peace in fragile contexts. Ultimately, all peace process are political and require well-resourced, empowered and competent diplomatic support.

In the late 1990s, the diplomatic corps of several DAC member states were subject to public criticism due to of the high cost and perceived luxurious lifestyle of diplomats posted abroad. There was a sense that the new age of technology and the globalisation of air travel should be able to significantly reduce the resources allocated to resident embassies and permanent diplomatic representation in foreign countries (Spies, 2019[2] $)$. At the same time, the geopolitical landscape underwent significant transformation, especially following the 11 September, 2001 attacks in the United States. The foreign policy agenda in several DAC member states shifted from the optimism of the 1990s, which was characterised by widespread global democratisation and vast expansion of international co-operation, to a focus on international terrorism and insecurity (Leffler, 2011[24]). Security concerns assumed greater importance among foreign policy priorities supplanting the diplomatic corps' core competencies of political dialogue and co-operation. This trend was further intensified by the growth of terrorist networks and global refugee and displacement crises.

A focus on international peace and security, countering terrorism, and heightening the efficiency of diplomatic relations are important and legitimate priorities. However, the tools and approaches championed by diplomatic actors are critical to addressing peace and security in fragile contexts, mitigating terrorism and displacement, and achieving other foreign policy objectives. Conflicts cannot be resolved without political processes, positive peace cannot be established without a focus on governance and co-operation, and strong diplomatic relations cannot be sustained without a degree of permanence in diplomatic relations.

\section{Issues of fragility will not wait}

Growing pressures on diplomacy and diplomatic priorities in fragile contexts are not confined to bilateral relationships - multilateral diplomacy is also facing significant challenges. Confidence is diminishing both in multilateral institutions and in the relationships between key stakeholders within the multilateral system (Lupel, 2019[23]). Most of the tools and mechanisms used to address violent conflict and fragility are coordinated, mandated or implemented through multilateral diplomacy (Spies, 2019 ${ }_{[2]}$ ). It underpins the global governance system for peace and security engagement, determining when the international community can legitimately intervene, and shapes the narratives, priorities and behaviour of international peace efforts. The erosion of multilateralism is hurting the ability of the international community to respond to transnational existential threats such as climate change and the COVID-19 pandemic. It also risks damaging the ability of the international community to effectively promote peace and address fragility. The growing tensions in global international co-operation underline the need to be creative and adaptive in efforts to craft consensus and navigate diplomatic pathways to agreement on peace and security efforts in fragile contexts. 
The rest of this paper examines the challenges and policy implications of three key functions fulfilled by diplomatic actors for peace in fragile contexts: (1) diplomacy as global governance; (2) diplomats as peacebuilders; and (3) diplomats as leaders, enablers and communicators. 


\section{Diplomacy as global governance}

\section{What does the global governance system look like?}

Maintaining the global governance system is one of the primary functions of diplomacy. From the UN Security Council, to the governing bodies of different regional organisations and other multi-stakeholder fora for diplomacy, such as the G20, G7, and G7+ group of fragile and conflict-affected countries, diplomatic actors, and diplomacy of different types co-ordinate collective action at the global and regional levels to address transnational challenges, including those related to international peace and security and leaving no one behind (Global Challenges Foundation, 2017[7]).

Several of the main multilateral organisations through which multilateral diplomacy and global governance are enacted were created explicitly to establish peace and security, either at the regional or global level. The co-ordination and governance achieved through these venues has been successful in many cases. The EU was founded on the belief that economic integration and co-dependency would prevent future conflicts in Europe following the Second World War (Spies, 2019 $\left.{ }_{[2]}\right)$. Today, the EU also plays a role in coordinating European responses to peace and security worldwide, enacted by member states themselves and EU agencies such as the European External Action Service (EEAS) and the EU Military Staff. The African Union (AU) also has the stated objective to achieve greater unity, cohesion and solidarity between its members, and thereby bring about a peaceful continent (ACCORD, 2014 $\left.{ }_{[8]}\right)$.

However, the global governance system is not comprised solely of these international organisations. It encompasses all institutions, policies, norms, procedures and initiatives through which states co-ordinate their responses to transnational and global challenges (United Nations, 2014[25]). The OECD Development Assistance Committee (DAC) is one such institution - and the recommendations, standards and initiatives enacted by the DAC, such as the Recommendation on the Humanitarian-Development-Peace Nexus, form part of the global governance system for development co-operation (OECD, 2018[26]). Thus, global governance extends beyond governance of multilateral organisations and the management of peace and security. It impacts on other pillars of the international community's engagement in fragile contexts, including both development co-operation and humanitarian assistance.

The extent to which multilateral diplomacy truly functions as a governance mechanism varies between regions and organisations. In Europe, the political and economic integration is profound. In Africa, too, the mandate and reach of the AU is expanding. Across Africa, deliberate efforts are underway to improve coordination and co-operation, particularly around issues of economic integration and peace and security, including through the expansion of the African Peace and Security Architecture (APSA) (Box 2.1). The AU "Silencing the Guns" initiative articulates this vision of increased regional integration and acknowledges that peace is a multidimensional concept, and requires efforts to tackle issues such as climate change and the absence of human capital (ACCORD, 2014[8]). However, political and economic integration is not a prerequisite for global governance. All countries and people are to some extent part of the global governance system, being influenced by the norms, standards and rules set out through diplomacy at the highest level. The Universal Declaration of Human Rights, for example, is not predicated on regional or global integration. It is a product of diplomacy that sets out a number of basic human rights to be enjoyed by all people, and affects our lives through norms and persuasion (İlgü Özler, 2018[27]). 


\section{Box 2.1. The African Peace and Security Architecture: From peaceful contexts to a peaceful continent}

The African Peace and Security Architecture (APSA) is the core institutional framework for the African Union (AU) and the Regional Economic Communities (RECs) dealing with issues of peace and security on the continent. APSA consists of five pillars: the Peace and Security Council (PSC), the Panel of the Wise, the Continental Early Warning Mechanism, the African Standby Force, and the Peace Fund. These entities, together with their regional counterparts in the RECs, address peace and security across the conflict cycle from prevention to crisis management, conflict resolution, and peacebuilding (African Union Commission, 2015[28]).

The PSC is the key organ for decision-making on issues of peace and security in Africa. It provides political leadership and legitimacy to interventions and operations addressing peace and security across the continent. In 2019, it responded to several conflicts including those in the Central African Republic, Libya, Somalia, South Sudan and Sudan (Woldemichael, 2020[29]). While the council has made great progress over the last two decades, significant challenges remain relating in particular to the relationship between the PSC, AU member states and the RECs (Woldemichael, 2020[29]).

The biggest challenge facing APSA is financing. The AU finances its peace support operations, as well as other operational activities contributing to peace such as preventive diplomacy and mediation, through the AU Peace Fund. Between 2008 and 2011. African states contributed only 2\% of total endowments to the Fund, raising questions about its sustainability. However, following the July 2016 AU assembly, African states committed to providing an increase in predictable financing. Endowments from African states amounted to USD 137 million for 2017-19 and are expected to reach USD 400 million by the end of 2020 (African Union Commission, 2019[30]).

Taking into consideration the profound security challenges that Africa currently faces, such as the crises in Cameroon and the Sahel, USD 400 million is still insufficient to effectively address security challenges across the continent. UN multidimensional peacekeeping operations in the Central African Republic (MINSUCA), the Democratic Republic of the Congo (MONUSCO), Mali (MINUSMA) and South Sudan (UNMISS), all have annual budgets of over USD 1 billion. AMISOM alone has an annual budget of more than USD 350 million, and is supported by a UN operation with an annual budget of more than USD 500 million (Forsberg, 2020[13]). However, the political momentum from African states behind the fund represents a significant step towards sustainable financing of peace and security on the continent.

Global governance is an evolving product of continuous diplomatic communication and takes different shapes and forms depending on the context and issue at hand. It is not composed of a static set of institutions and mechanisms (Global Challenges Foundation, 2017[7]); rather, global governance reacts to new fissures and challenges as they appear, creating new fora and instruments to address challenges. Crucially, it is dependent on the continuity of communication inherent to the diplomatic profession.

Global governance is not always effective, or even functional (Commission on Global Security, Justice \& Governance, 2015[107]). A UN Committee for Development Policy report from 2014 argues that international co-operation and the resulting governance mechanisms are not working well for development co-operation (United Nations, 2014[25]), and disagreements between key stakeholders of the UN Security Council are damaging global governance of peace and security (Gowan, 2019[31]). However, it is essential for the international community's efforts to support peace and address fragility and other global public "bads", that international co-operation at the highest level exists and evolves. The following section examines the implications of the state of global governance for the ability to support peace and address the root causes of fragility. 


\section{How does global governance affect the ability to make peace on the ground?}

The global governance system is essential to effectively address global public "bads", such as armed conflict and insecurity, but it can also inadvertently complicate these issues. When it works well, it provides predictability, stability and order to international community responses. However, when international cooperation is lacking, the ability to support peace, development and humanitarian assistance on the ground is constrained (United Nations, 2014[25]). Priorities and co-operation in institutions such as the UN Security Council permeate down to organs and actors at lower levels. When the work of the Security Council is successful, it enables joint and forceful responses and actions that are effective in supporting peace. When it is not successful, it hinders such actions and can actively fuel dynamics that drive conflict in fragile contexts.

High-level diplomacy has three primary roles that affect the ability to support peace: it establishes norms, sets rules and standards, and mandates responses across the conflict cycle. The norms, rules and mandates set forth in high level fora for diplomacy do not exist in a vacuum. Their properties and effects influences peace efforts in fragile contexts including through their relationships with each other and diplomacy at other levels. Understanding these dynamics and roles is crucial to determining the choice of channels and tools for effective conflict response and management.

\section{Establishing norms contributing to peace and security}

The normative effects of decisions, resolutions and agreements in high-level diplomatic fora are among the strongest tools to maintain international peace and security. Such instruments include norms on governance, democracy, international co-operation and human rights that directly impact on the risk of armed conflict in fragile contexts, as well as norms concerning the international community's engagement to support peace in fragile contexts, such as those championing the protection of civilians and international humanitarian law. In fact, one of the primary objectives of many multilateral and regional organisations is to establish and protect shared or universal values (United Nations, $2019_{[32]}$ ). Despite few truly binding and enforceable instruments to uphold such values, multilateral diplomacy is actively promoting peace worldwide. During a commemorative meeting of the UN General Assembly observing the United Nations International Day of Multilateralism and Diplomacy for Peace in April 2019, the President of the General Assembly proclaimed that "there is no doubt that the United Nations has transformed the fate of mankind, saving millions of lives throughout the world" (United Nations, 2019[32]).

The normative (and in some cases legal) frameworks on governance, democracy, co-operation and human rights established through multilateral diplomacy, such as through the Charter of the United Nations, the African Charter on Democracy, Elections and Governance, and other resolutions and agreements, provide a framework for determining when and for what reasons external actors may legitimately intervene. They provide a bar against which actions, behaviours and events can be assessed. One rationale behind the transformation of the Organisation for African Unity (OAU) to the AU was the establishment of certain fundamental values and standards that all member states of the Union had to observe. These included respect for human rights and democratic governance, and the condemnation of unconstitutional changes of governments. This framework also mandates joint intervention by the AU when these fundamental standards are not upheld (Kioki, 2003 $\left.{ }_{[33]}\right)$. Other such normative frameworks are more specific and concern particular aspects of international peace and security. For example, UN Security Council Resolution 2417 on hunger, peace, and security highlights the link between conflict and hunger and condemns the use of starvation as a weapon of war. The Resolution has influenced the recent amendment of the International Criminal Court's statute, which extends the Court's jurisdiction to the use of starvation in non-international conflicts, and has increased pressure to protect food systems and ensure markets can function through both development, humanitarian, and peace means in times of crises (Beltrami, 2020[34]). 
Pressure from members of the UN Security Council has also been influential in promoting the participation of women in peace processes. UN Security Council Resolution 1325, which stresses the importance of women's equal and full participation as active agents in the prevention and resolution of conflicts, peacebuilding, and peacekeeping (United Nations, 2000 353 ), combined with an additional nine UN Security Council resolutions, collectively make up the Women, Peace and Security agenda (WPS). The agenda has increased attention to the gendered impacts of violence and conflict, as well as the importance of the equal involvement of women in all peace processes. As of January 2018, 72 countries had enacted national action plans to implement the WPS (USIP, 2018[36]).

Establishing and maintaining such norms has a persuasive effect. It increases the reputational cost of violating human rights or rebelling against a legitimate government, and shapes narratives around priority issues. It also improves the effectiveness of the response by external actors if they intervene in order to defend shared and agreed upon values and norms. One of the primary reasons that multilateral diplomacy is well placed to deal with global public "bads" is because it is better able to legitimise actions, and thereby achieve more sustainable results, since it is based on joint understanding and shared normative frameworks (Maull, 2020[37]).

A second normative purpose of agreements and actions achieved through high-level diplomacy is to strengthen the practices employed by the international community in peace efforts. Through the Declaration of Shared Commitments on UN Peacekeeping Operations, 152 countries and four international organisations committed to reinforcing peacekeeping through increased engagement around eight different priority areas. These included advancing political solutions to conflicts, enhancing the political impact of peacekeeping, and strengthening the protection of civilians (United Nations, 2018[38]). Another example, which is more limited in scope, is the DAC Recommendation on the Humanitarian-DevelopmentPeace Nexus. Through the Recommendation, DAC members committed to implement and incentivise more collaborative and complementary approaches to effectively support peace, development and humanitarian assistance, particularly in fragile contexts (OECD, 2019 $\left.9_{[12]}\right)$. The OECD tracks adherence to the Recommendation, but there are no enforceable legal provisions. Instead, the Recommendation works by setting norms and allowing for mutual pressure based on shared commitments among its adherents.

The normative frameworks that form the basis for, and which are enacted through, the global governance system are not universally accepted or common to all regions and organisations across the world. The universal values proclaimed by the UN are often accused of being those of a "liberal Western-style international order" (Maull, 2020[37]), including concepts such as human rights and democracy. While such values are not exclusive to the "liberal Western-style international order", their application is often based on conceptualisations derived from the "Western world". One major challenge to diplomacy, particularly multilateral diplomacy, today is the growing divergence of views on interpretation of these values. Norms around gender and human rights in UN peacekeeping operations, for example, are increasingly challenged by members of the Security Council (Boutellis, 2020[39]), and have prevented the Security Council from joining the UN Secretary-General's call for a global ceasefire in light of the COVID-19 pandemic (The Economist, 2020[40]) (Box 2.2).

These divergences and their impact on global international co-operation have a negative effect on the international community's ability to prevent and respond to conflict. Their consequences highlight the need to be agile and adaptive in the use of normative diplomatic tools - using the right fora for global governance for the right issues. The occasions on which the UN Security Council, or the UN General Assembly, is able to come together and jointly commit to values, norms and principles, constitute the most persuasive and effective means to promote conditions and practices conducive to peace. However, as noted above, this is not always possible, nor is it always effective, as the legitimacy of joint statements and declarations can be outweighed by other factors. For example, pressure and norms for governance in Africa can be more effective and perceived as more legitimate when achieved through African instruments and institutions, such as the African Charter for Democracy, Elections and Governance and the AU Peace and Security Council resolutions, on the basis that they represent "African Solutions to African Problems" (Duursma, 
2020[41]). Thus, in order to create and uphold an effective normative framework for peace and security, diplomatic actors must take into account not only what is possible, but also understand how it is perceived. They need to adapt, be agile, and find new avenues to shape norms and narratives where it is possible and effective for the particular moment in time and the issue at hand.

\section{Box 2.2. COVID-19 and the call for a global ceasefire}

On 23 March 2020, the UN Secretary-General issued a call for a global ceasefire in light of the COVID-19 pandemic, stating "it is time to put armed conflict on lockdown and focus together on the true fight of our lives". The ceasefire would allow humanitarians to access populations in need in areas otherwise deemed too insecure and dangerous. The pandemic was also seen as an opportunity to initiate negotiations between belligerents in conflicts around the world on the basis of a common need to mitigate the effects of COVID-19 (United Nations, 2020[42]).

In the first weeks after the appeal there were positive signs. The UN estimated that armed groups and governments party to a conflict in 11 countries had recognised the call by early April (Guterres, 2020[43]). Among them were several extremely fragile contexts particularly ill prepared to cope with the spread of disease and the consequences of the pandemic across multiple dimensions of fragility (OECD, 2020[44]).

Since mid-April, however, the call has lost momentum. Conflict data gathered by the Armed Conflict Location \& Event Data Project (ACLED) in June 2020 suggests that the ceasefire call has had little effect on the overall level of violence worldwide. The most positive reactions were statements of support with no commitment to action, and in several contexts, including Iraq and Mozambique, violence has increased since late March (ACLED, 2020[45]).

The International Crisis Group has identified four reasons for the limited impact of the ceasefire call (Gowan, 2020[46]):

- In some cases, one party in a conflict offered a ceasefire in response to the UN call, but other parties to the conflict did not respond.

- A lack of ceasefire architecture impeded efforts to take advantage of ceasefire offers. International mediators have been unable to travel and peacekeeping missions have been forced to operate at minimum capacity due to the pandemic, leaving few tools through which to operationalise a ceasefire.

- COVID-19 has not spread as rapidly in fragile and conflict-affected contexts as many expected. As of June 2020, there are signs that the pandemic is spreading in fragile contexts, but this development has not significantly affected the calculations of warring parties.

- It took the UN Security-Council more than three months to endorse the Secretary-General's ceasefire call. Had the Council acted earlier, it would have granted it additional political credibility and encouraged conflict parties to take the call more seriously. On 1 July 2020, the Security Council adopted Resolution 2532, expressing its support for the Secretary-General's appeal for a global ceasefire, possibly granting renewed momentum to the appeal (United Nations, 2020[47]).

\section{Setting rules and issuing mandates for international peace and security efforts}

In addition to playing a normative role, high-level diplomacy contributes to global governance by establishing legally binding and enforceable rules and standards for issues related to peace and security. As with norms, the rules and standards set by diplomacy regulate aspects of governance, human rights, and other factors affecting the risk of conflict, but also dictate when and how the international community must or is allowed to intervene and respond to peace and security issues. Furthermore, multilateral 
diplomacy is required to issue mandates for external peace and security actions. Thus, high-level multilateral diplomacy establishes the framework of global governance and provides many of the tools necessary for its enforcement.

Some of the most robust rules used to influence governance and human rights compliance are those that can be enforced by international judicial systems such as the International Criminal Court (ICC) and the International Court of Justice (ICJ). The territorial and subject-matter jurisdictions of these courts vary, but they all share the ability to issue legal verdicts that bind states or individuals to take certain actions or that make them subject to penalties. In the case of the ICC, the subject-matter jurisdiction is defined by the statute of the court, which lists the following categories of crimes: genocide, crimes against humanity, war crimes and crimes of aggression (ICC, 2011 ${ }_{[48]}$ ). People in the 123 member states to the court can thus be prosecuted for committing any crimes falling within those four categories, regardless of their legal status in the country in which the crimes were committed (Felter, 2019 $9_{[49]}$. However, international rules and standards can be enforced through other means as well. Multilateral bodies can issue sanctions ranging from comprehensive economic and trade sanctions to targeted measures such as arms embargoes, travel bans, and financial or commodity restrictions. Since 1966, the UN Security Council has established 30 sanctions regimes on 24 countries and three terror organisations. As of July 2020, there are 14 UN Security Council mandated sanctions regimes which support the political settlement of conflicts, nuclear nonproliferation, and counter-terrorism (United Nations, 2020[50]).

The rules and standards governing when and how the international community should respond to armed conflicts are set out mainly in the charters and constitutive acts of international organisations. The Charter of the United Nations provides such rules under Chapter VI and VII, which allow both non-armed and armed intervention to settle disputes (United Nations, 1945[6]). The AU Constitutive Act similarly establishes rules for when and how the $\mathrm{AU}$ is allowed and required to intervene through peaceful or military means to prevent or respond to armed conflict and violence (Kioki, 2003[33]). Article 5 of NATO's founding treaty also commits all members to intervene whenever a NATO ally is attacked (NATO, 1949 ${ }_{[51]}$ ).

These rules overlap with normative frameworks and often function like norms, albeit with an additional level of enforceability. As highlighted by the influence of UN Security Council Resolution 2417 on hunger, peace and security on the amendment to the International Criminal Court's statute, normative pressure from multilateral diplomacy can also translate into rules and enforceable standards. As with normative frameworks, diplomatic actors need to be agile and adaptive in their efforts to establish rules and standards, seizing opportunities as they arise and crafting pathways where they are pursuable.

Based on existing rules and standards, multilateral diplomacy can also mandate international peace efforts, operating at levels ranging from the UN Security Council to regional organisations. All the multilateral peace operations examined in Security Actors in Fragile Contexts (Forsberg, 2020[13]) received their mandates from the UN Security Council, with some receiving additional mandates from regional organisations and bilateral agreements. The NATO Resolute Support Mission in Afghanistan, for example, derives its mandate not only from a bilateral agreement between NATO and the Afghan government, but also from UN Security Council Resolution 2189, which underscores the importance of continued international support for the stability of Afghanistan, including through the NATO mission (United Nations, 2014[52]). However, mandated peace operations are not the only tool used to uphold the norms and standards set by high-level diplomacy. The UN and many other multilateral and regional organisations are involved in a range of political and diplomatic missions, from long-term governance support to mediation. These missions and functions of diplomacy are examined further in Chapter 3.

\section{All efforts to address fragility and support peace are dependent on high-level diplomacy.}

The efforts of DAC members and multilateral organisations are dependent on the efficacy of multilateral diplomacy. DAC members can legitimately promote forms of governance perceived as conducive for sustained peace because of the existence of mutually agreed upon standards that detail what such "good 
governance" should look like. Similarly, the United Nations Hybrid Operation in Darfur (UNAMID) - the joint deployment of more than 10000 troops in the Darfur region of Sudan by the AU and UN through the African Union - is possible only because of high-level diplomatic co-operation between the UN Security Council and the AU Peace and Security Council (Whineray, 2020[53]).

Even effective development co-operation practices are often dependent on multilateral diplomacy. The Sustainable Development Goals (SDGs), the Addis Ababa Action Agenda, the Busan Partnership for Effective Development Co-operation, the New Deal for Engagement in Fragile States and the DAC Recommendation on the Humanitarian-Development-Peace Nexus are all products of multilateral diplomacy (OECD, 2019[12]). These normative frameworks govern and promote good practices for development co-operation in fragile contexts, focusing on the root causes of fragility and integrating International Humanitarian Law and human rights into activities across the pillars of engagement. Such resolutions, agendas, deals and recommendations can strongly influence the narratives and priorities at the core of engagement by the international community in fragile contexts. Furthermore, donor conferences and similar events are important diplomatic tools for focusing attention and mobilising resources to issues and contexts in need.

Humanitarian, development and peace actors in fragile contexts are dependent on, and should, when necessary, co-operate with diplomatic missions engaged in multilateral diplomacy, in order to ensure balanced and well-informed decisions that take into account the perspectives of all three pillars of engagement. 


\section{Diplomats as peacebuilders}

\section{Political action and dialogue}

The core strength and competency of diplomatic actors is continuous communication and dialogue. This is the case for high-level multilateral diplomacy, where diplomatic relations and dialogue forge narratives, structures, and priorities conducive for coherent engagement in fragile contexts, as well as for direct diplomatic engagement by OECD Development Assistance Committee (DAC) members and multilateral organisations in fragile contexts. Diplomatic actors engage in political dialogue with stakeholders in fragile contexts to further public interest and foreign policy (Spies, 2019 $\left.{ }_{[2]}\right)$. These objectives can overlap significantly with development priorities to address the root causes of fragility, violence, and conflict (Desai, $\left.2020_{[15]}\right)$. As diplomatic actors are the primary political actors abroad, and politics is at the root of armed conflict and fragility, diplomatic dialogue and communication function as a key feature of effective engagement in fragile contexts.

\section{The presence of DAC member and multilateral diplomatic actors in fragile contexts}

A total of 571 resident embassies and permanent delegations are deployed by DAC members (Lowy Institute, $2019_{[20]}$ ) in 56 of the 57 fragile contexts, all of which engage in political dialogue with governments and other stakeholders. In addition, 60 active multilateral political missions operate across the world, almost half of which are UN missions. The second main operator of civilian political missions is the Organisation for Security and Co-operation in Europe (OSCE), which currently has 16 missions deployed across central Asia, the Caucasus, and Eastern Europe. The EU, AU, and the different African Regional Economic Communities, as well as the Organization of American States (OAS) (Box 3.1) also operate political missions to support peace across the world. Thirty-two of the missions observed for this study operate entirely or in part in fragile contexts, with 39 out of 57 fragile contexts receiving some form of support through multilateral political missions.

The UN oversees the largest number of political missions and deploys the greatest number of personnel, primarily in fragile contexts in sub-Saharan Africa and the Middle East and North Africa However, the region with the largest number of political missions is Europe and Central Asia Figure 3.1, where OSCE missions ensure strong multilateral political support. The relatively weaker presence of multilateral political missions in Latin America and the Caribbean, South Asia and East Asian and the Pacific, could be due to other operational cultures and approaches among organisations in those regions, but also, to some degree, less imminent challenges related to political aspects of conflict and fragility. 
Figure 3.1. Multilateral political missions by region and organisation, 2020

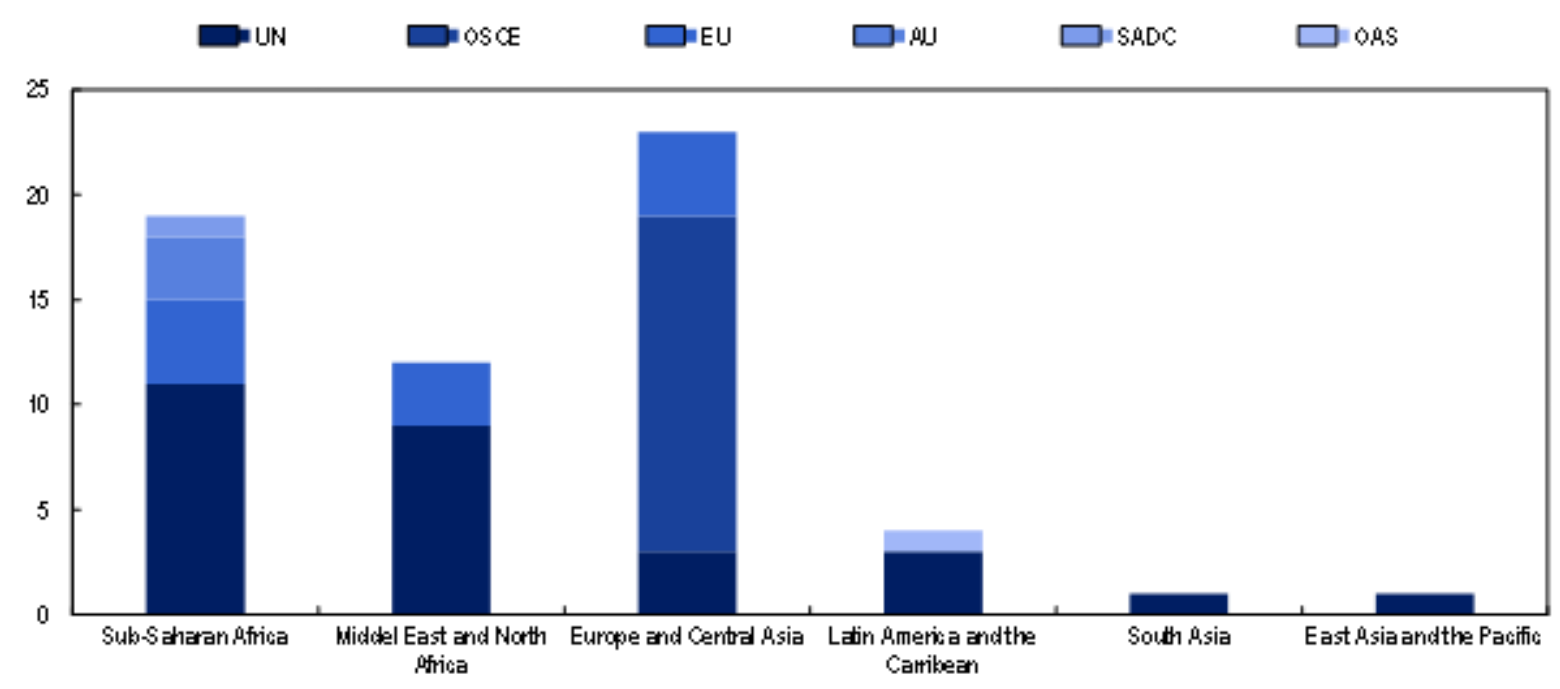

Note: The multilateral political missions all have different mandates, sizes and functions.

Source: This graph is produced based on the authors' calculations using the SIPRI (SIPRI, 2020[108]) Multilateral Peace Operations Database https://www.sipri.org/databases/pko and desk research on multilateral organisations' own reporting of their political country presence.

\section{Box 3.1. Supporting the fight against corruption and impunity in Honduras}

Honduras has made significant improvements across several dimensions of fragility in recent years, including in the political dimension (Desai and Forsberg, 2020[19]). The OAS has worked with the Honduran government to fight corruption and impunity in the country, in particular through the Mission to Support the Fight against Corruption and Impunity in Honduras (MACCIH), which was deployed in early 2016 (OAS, 2020[54]). The mission was inspired by a similar UN operation entitled the International Commission against Impunity in Guatemala (CIClG).

MACCIH supported the Honduran government by identifying sectors sensitive to corruption (e.g. public procurement, construction, public health, customs, mining, justice and security), where better regulation and management structures were needed. The mission also proposed strategic reforms to help prevent and prosecute cases of corruption (OAS, 2020[54]). MACCIH played a critical role in combating entrenched corruption and impunity in Honduras, and enjoyed broad popular support in the country (Gonzalez and Sherman, 2020[55]). The mission worked to build capacity among Honduran prosecutors, and put political pressure on actors to implement reforms necessary to combat corruption and impunity (OAS, 2020[54]).

The mandate of the mission lapsed in January 2020, and the OAS and the Honduran government failed to reach a consensus on a new covenant to continue the mission. The OAS Secretary-General Luis Almagro argued that the end of the mission represented "a negative event in the fight against corruption and impunity in the country" (Gonzalez and Sherman, 2020[55]). However, while the mission was not able to extend its four-year mandate, it has had a positive effect on the level of corruption and impunity in Honduras, and stands as an example of a political approach that regional and multilateral organisations can use to promote strategically important reforms. 


\section{Diplomatic dialogue with stakeholders in fragile contexts contributes to long-term processes and relations that create and sustain peace}

As noted earlier, diplomacy, as enacted by diplomatic actors, is primarily a tool to further the national interests and foreign policy agenda of the government that the diplomat represents. It is important to state, however, that foreign policy agendas, unlike development co-operation or humanitarian assistance, vary significantly between DAC members. While donors and multilateral organisations might also focus on different development outcomes and use different approaches, their development co-operation practices share a number of objectives and principles (OECD, 2011 ${ }_{[56]}$ ), and use the same framework to measure progress against the SDGs (United Nations, 2015[57]). Foreign policy is more diverse and may differ significantly among countries. However, nearly all DAC members and multilateral organisations, share foreign policy objectives to promote international peace and security, and to tackle global public "bads" that contribute to fragility across the world, especially in already fragile contexts. Such shared priorities can unite peace and development objectives with foreign policy around key factors, or "leverage points". Under these conditions, diplomatic engagement and dialogue can add as much value to the public and national interest of the sending state, as to "global public goods", especially in contexts where DAC members share broad foreign policy objectives.

One of these "leverage points" where foreign policy and development priorities often converge, and where diplomatic tools are particularly relevant, is the promotion of inclusive governance. Inclusive governance refers to "a normative sensibility that stands in favour of inclusion as the benchmark against which institutions can be judged and also promoted" (Hickey, 2015[58]). There is strong agreement that inclusive governance is central to achieving sustainable development (OECD, 2020[59]) and sustained peace (United Nations, 2015[57]). Horizontal inclusion among elites from competing groups, as well as the public, in terms of both who is included in decision-making processes and who benefits from the distribution of resources and wealth, reduces the risk of conflict recurrence and is important to sustaining peace (OECD, 2020[59]).

Inclusive governance can be promoted through development assistance and support for civil society organisations and other inclusive institutions. However, diplomatic actors can also contribute to this process through inclusive dialogues with different national stakeholders, amplifying voices that would otherwise be marginalised. Diplomatic actors can also encourage inclusive governance through political dialogue and engagement with ruling elites. For instance, as part of the "Drive for Democracy" initiative launched in 2019, Sweden has committed to promoting democratic institutions abroad, not only through development assistance, but also by leveraging the power of Swedish diplomacy - calling out undemocratic practices, forming coalitions to promote democratic processes and institutions, and leveraging political power acquired through Sweden's trade, development co-operation, and security policies (Minister for Foreign Affairs Margot Wallström, 2019[60]). While the initiative represents a high-level global commitment to democracy, the approach permeates down to embassies and development cooperation offices in fragile contexts. It encourages integrated development-diplomatic approaches to support democratic institutions through multiple tools, including development aid and diplomacy, and leverages political influence to encourage inclusive political settlements.

Gender equality is another area where foreign policy objectives to ensure peace overlap with development co-operation priorities. Women are disproportionality affected by conflict and fragility, as reflected in the WPS agenda. Moreover, peace is more sustainable when women are equally and meaningfully included in peace processes (OECD, 2017[61]) (Box 3.2). Much like inclusive governance, gender equality is a common objective of development co-operation and a catalyst for progress on fragility (United Nations, 2015[57]). However, it cannot be achieved without political engagement and politically informed decisions. The study Gender Equality and Women's Empowerment in Fragile and Conflict-affected Situations found serious weaknesses in donors' understanding of how political economy factors shape conflict, fragility and gender relations. The theories of change employed in many of the programmes reviewed were not well grounded in political realities, raising questions about their potential and sustainability (OECD, 2017[61]). 


\section{Box 3.2. Equal and meaningful participation of women in conflict prevention and peacebuilding}

It is now recognised that the equal and meaningful participation of women in conflict prevention and peacebuilding improves outcomes of peace processes. However, peace efforts are still marked by lack of gender equality. Between 1992 and 2018, women accounted for only $3 \%$ of mediators, $13 \%$ of negotiators and $4 \%$ of signatories in major peace processes. Furthermore, only a fifth of peace agreements made reference to women (Council on Foreing Relations, 2019[62]). Improving gender equality in peace processes remains an untapped source of potential in peacebuilding worldwide.

The participation of women in peace processes can take different forms with varying effects. The inclusion of women in formal peace negotiations, for example, increases the chances of peace agreements lasting more than two years by $20 \%$ and over 15 years by $35 \%$ (O'Reilly, Súilleabháin and Paffenholz, 2015 $\left.5_{[63]}\right)$. The level of influence of women in peace processes also matters, with the chances of reaching a peace agreement increasing significantly if women can exercise moderate to high degrees of influence over peace negotiations (O'Reilly, Súilleabháin and Paffenholz, 2015[63]). Such influence can also be exercised without formal participation (Porter, 2003[64]). In Liberia, groups of women surrounded buildings to make peace negotiators stay in the room until an agreement was reached (Diaz and Tordjman, 2012[65]). Gender equality in peacebuilding is also crucial as "the exclusion of women who are primarily affected by conflict - from peacebuilding activities invariably limits the comprehensiveness of the process" (Adjei, 2019[66]).

Women's participation in peacekeeping has also been shown to have significant benefits for peace. Since the adoption of UN Security Council Resolution 1325, the UN has urged members to increase the number of women in peacekeeping forces to improve the outcomes of missions. Female security sector officials, for example, frequently have access to populations and venues that are closed to men, which allows them to gather otherwise inaccessible information about potential security risks (Olsson and Tejpar, $\left.2009_{[67]}\right)$. Furthermore, it has been argued that gender equality in peacekeeping results in outcomes that are "more reflective of the societies with which they deal, thus allowing them a better chance to achieve a sustainable peace" (Hudson, 2005[68] $)$.

\section{There is potential for stronger development-diplomatic co-ordination}

In areas where development and foreign policy objectives overlap - particularly on issues contributing to peace and stability such as governance and gender - development and diplomatic capacities can and do complement each other. The DAC Recommendation on the Humanitarian-Development-Peace Nexus calls for diplomatic leadership and engagement to support inclusive political systems that deliver equitable development and lasting peace. Diplomatic actors can leverage their political knowledge, legitimacy, and access to support and incentivise important political reforms and processes contributing to peace (OECD, $\left.2019_{[12]}\right)$.

Adopting an integrated approach by ensuring diplomats have knowledge of development co-operation dynamics, can also add a layer of political leverage to the diplomatic tool box, helping diplomats achieve foreign policy objectives that are aligned with development priorities. Using development efforts to realise foreign policy objectives is controversial and has not always been effective. However, politically informed and co-ordinated conditionality, which seeks to strengthen the demand side for reforms within the state and with civil society, and incentivise sought for reforms on the supply side, can be effective (Vanheukelom, $2012_{[69]}$ ). It should be noted, though, that "these measures don't create political reform readiness such as respect for human rights, rule of law, and more open access democracies", but do "contribute to tilting the balance and may - when cleverly applied - reinforce the hands of reformers over time" (Vanheukelom, 2012[69]). 
The political awareness and access of more collaborative development-diplomatic arrangements is of particular importance in fragile contexts. Without knowledge and access to political networks, there is a real risk that development approaches that address issues contributing to fragility will be ineffective, or even do harm. Working together and addressing "leverage points" to achieve systemic results on fragility, both through development assistance and diplomatic support and pressure, can reduce the risk of doing harm and increase the chance of achieving good results. Several countries have launched initiatives to improve the complementarity of development and diplomatic practices. Canada, France, and Sweden, for example, have promoted feminist foreign and international assistance policies that combine a variety of tools, including political dialogue and pressure to further gender equality (Thomson, 2020[70]). Other countries have taken integration a step further, by merging diplomatic and development agencies with varying results (Young-Powell, 2019 ${ }_{[71]}$ ), most recently in the United Kingdom.

There is significant potential in integrated approaches to leverage the multi-layered political knowledge of diplomatic actors, as well as their political networks, to ensure that development co-operation, peacebuilding and conflict prevention in fragile contexts take into account and address political factors. In the absence of this knowledge, there is a risk that prevention, peacebuilding and development co-operation will become too process driven, lack a sustainable theory of change, and miss key political causes of armed conflict, violence, and fragility. However, such integration should not come at the expense of development co-operation principles, priorities, or competencies (Gulrajani et al., 2020[72]).

\section{Third-party diplomacy: The diplomacy of peacemaking}

Third-party diplomacy is the type of diplomacy most closely related to peacemaking ${ }^{6}$ and peacebuilding. Multilateral and bilateral diplomacy are based largely on mutual exchange and communication - promoting peace and preventing conflict by improving trust and communication where circumstances allow at least some form of communication to occur. However, in conflict-affected contexts, such circumstances are often absent, and the prospects for direct diplomacy between two parties locked in civil war are slim. The role of third-party diplomacy is to create opportunities for diplomacy where they are otherwise absent, through varying degrees of commitment and intermediation between parties (Spies, 2019[2]).

Third-party diplomacy can be conducted by a variety of actors or groups of actors. The most basic form relies on so-called "good offices." Diplomacy through good offices implies that a third-party facilitates communication between conflicting parties by offering facilities and logistical support. The "good officer" does not in general participate actively in peace-making processes. "Good offices" are maintained by a range of actors, including the UN Secretary-General and the AU Panel of the Wise, as well as DAC members such as Switzerland (Spies, 2019 $\left.{ }_{[2]}\right)$. They are more dependent on their legitimacy, perceived neutrality, and ability to command respect than formal political powers.

\section{Mediation: A core contribution of the international community to peace}

Mediation is perhaps the most explicit type of third-party diplomacy, and has received considerable attention in peace literature (e.g. Duursma, 2020[41]; Svensson, 2007[106]). Mediation is employed at all stages of peace processes, even during full-scale war where parties hold mutually exclusive and fixed positions with high levels of distrust and resentment. The goal of mediation is to help parties find a solution to disputes that is acceptable to all. This process often involves bridging information gaps and resolving commitment problems, but can also entail more coercive strategies such as promised benefits and threats of punishment (Wallensteen and Svensson, 2014[10]). Mediation is an important tool for peacebuilding. Of the 165 negotiated settlements ${ }^{7}$ reached in conflicts in fragile contexts between 1991 and 2017, only 19 were concluded without the involvement of a third-party mediator (Duursma, 2020[41]). The success rate of mediation varies significantly with the context, type of mediator, and conflict dynamics - and reaching a 
politically negotiated peace agreement is only the first stage in a longer peace process. Nonetheless, mediation remains an essential, flexible and effective tool for peace (United Nations, 2017[73]).

Mediation efforts can both be public and high profile, such as the UN-led mediation efforts in December 2018 between the Yemeni government and Huthi rebels (International Crisis Group, 2019[74]), or may be more discreet and take place under the radar, often over longer periods of time. UN Secretaries-General have traditionally played an active role as mediation actors, but are increasingly transferring hands-on responsibilities to representatives and mediators at lower levels (United Nations, 2011[11]). Other multilateral and regional organisations such as the AU, the OAS, and the OSCE are also conducting thirdparty diplomacy and mediation. However, mediation and third-party diplomacy is not only an endeavour for multilateral organisations. A range of countries are actively conducting third-party diplomacy, including mediation, as part of efforts to support international peace and security. Some DAC members, including "middle powers" such as Norway, New Zealand and Switzerland specialise in mediation (Box 3.3) (Spies, 2019[2]).

The growing academic literature on international mediation qualitatively and quantitatively examines the conditions under which mediation processes can help bring armed conflicts to a peaceful end. This literature is crucial as mediation has the potential to be a cheaper and more effective tool to assist in conflict resolution than other policy tools, such as sanctions, military engagement or development co-operation (Wallensteen and Svensson, 2014 $\left.{ }_{[10]}\right)$. However, only a minority of mediation attempts in internal conflicts have led to the cessation of hostilities owing to the efforts of the mediator (Mehrl and Böhmelt, 2020[75]). Examining the conditions under which mediation is effective, and translating such findings into policy and practice could greatly improve international responses to armed conflict.

Recent scholarly studies, for example, have found that the type of leverage a mediator possesses in a conflict affects the results of mediation efforts. Capability leverage, measured as the economic resources and power of the mediator, contributes to the achievement of short-term success. However, credibility leverage, which is determined by historical and cultural ties that bolster a mediator's contextual knowledge of a conflict, generates a more durable peace (Reid, $\left.2015_{[76]}\right)$. Legitimacy has also been shown to affect the outcome of mediation. African mediators more effectively mediate civil wars in Africa because of a high degree of legitimacy derived from the conviction within African states that African solutions should be applied to African problems (Duursma, 2020[41]). A third important finding is that leadership changes among mediators can lower mediation effectiveness and prolong conflict durations (Mehrl and Böhmelt, 2020[75]). While these are just a sample of findings from the mediation literature, they highlight the importance of analysis and contextual understanding as prerequisites to mediation efforts. The ability to act as an effective mediator depends on the context, and extends beyond principles such as neutrality. 


\section{Box 3.3. Switzerland: 150 years in the service of peace}

Switzerland's involvement in third-party diplomacy today represents the continuation of a 150-year-old engagement in international peace and security. Around 1870, Switzerland adopted a more active foreign policy, contributing to global peace by organising international peace conferences and offering "good offices" in countries around the world (Lanz and Mason, 2012[77]).

The current configuration of Switzerland's peace policy dates back to the end of the Cold War. Centred around "human security", the policy seeks to position Switzerland as a more active player in the world, and invokes the phrase" active neutrality" to this end. Since domestic politics limit Swiss participation in military peacekeeping missions, the government has emphasised civilian peacebuilding, and mediation in particular (Lanz, 2011 [78]). Today, the promotion of peace is anchored in the federal constitution and constitutes one of Switzerland's main foreign policy objectives. Switzerland is also committed to strengthening its "good offices", especially its mediation capabilities (FDFA, 2020[79]).

Since 2000, Switzerland has been involved in approximately 20 peace negotiations processes in 15 countries (Conseil fédéral, 2018[80]). In Mozambique, they chaired the International Contact Group which facilitated peace negotiations between the government and the opposition party Resistência Nacional Moçambicana (RENAMO), from 2017 to the signing of the peace agreement in 2019. The Swiss ambassador to Mozambique, Mr Mirko Manzoni, acted as the Chief Mediator in the negotiations (Conseil fédéral, 2018[80]). Following the signing of the peace agreement, Manzoni was appointed as the Personal Envoy of the UN Secretary-General for Mozambique, and has continued to provide good offices support, facilitating dialogue between stakeholders in the country (United Nations, $2019_{[81]}$ ).

Switzerland's experiences in peace mediation (Lanz and Mason, 2012[77]) identifies a number of key challenges facing the country in its mediation efforts. Notable among these is the challenge of coherence. Mediation is not a standalone tool - a number of other policy areas and tools can be used to support (or derail) peace processes. Trade policy, development co-operation and security assistance are all relevant tools that affect the ability to facilitate political peace processes. Promoting peace is therefore a whole-of-government activity and the challenge is to ensure complementarity and coherence between different policy areas as well as the government agencies in charge of them. Switzerland's experience supporting the peace process in Sudan showed that regular contact between individuals responsible for key issues in different government agencies can facilitate the implementation of a coherent approach (Lanz and Mason, 2012[77]).

\section{Third-party diplomacy across the conflict cycle - a versatile tool}

While mediation and third-party interventions are often associated with the management and settlement of active armed conflict, they can also be used to prevent conflict onset and recurrence. The UN has engaged in "preventive diplomacy" since the term was coined by Secretary-General Dag Hammarskjöld in the 1950s (United Nations, 2011 [11]). The current conceptualisation of preventive diplomacy was introduced in the seminal An Agenda for Peace report in 1992, where it is referred to as diplomatic action taken, at the earliest possible stage, "to prevent disputes from arising between parties, to prevent existing disputes from escalating into conflicts and to limit the spread of the latter when they occur" (United Nations, 1992[82]). Conflict prevention extends beyond diplomatic efforts to prevent conflicts emerging and escalating, and involves activities to build "structural resilience", addressing the root causes of fragility and armed conflict (Desai, 2020 $[15])$. However, the journey "from fragility to resilience" (Desai and Forsberg, 2020[19]) is far from over for many fragile contexts. Outbreaks still occur and preventive diplomacy is a key tool to prevent their escalation into large-scale armed conflicts. 
In the past two decades, the international community, including multilateral and regional organisations and many DAC members, as well as states experiencing fragility, has developed a plethora of preventive mechanisms. These include the development of early warning systems by the AU, the EU and the OSCE (United Nations, 2011 ${ }_{[11]}$ ); targeted funding mechanisms for rapid response, such as the EU's Instrument contributing to Stability and Peace $\left(\mathrm{EU}, 2014_{[83]}\right)$; the establishment of dedicated prevention structures, such as strengthening the ECOWAS Council of the Wise; and the continued use of special envoys. The 60 multilateral political missions currently deployed around the world also include, in many cases, a preventive diplomacy mandate, providing a forum for the peaceful settlement of disputes, including through the use of good offices. These tools enable the international community, often discreetly and quietly, to assist in diffusing conflicts by facilitating peaceful settlements (United Nations, 2011 ${ }_{[11]}$ ). For example, the OSCE High Commissioner on National Minorities has helped to defuse tensions over national minority issues in many countries through quiet diplomacy (United Nations, 2011 [111).

In addition, third-party diplomacy forms part of post-conflict efforts to sustain peace. Research shows that $60 \%$ of all armed conflicts reoccur (Gates, Mokleiv Nygård and Trappeniers, 2016 ${ }_{[84]}$ ), highlighting the need to maintain conflict prevention in the aftermath of any settlement. Peace agreements are fragile and depend on continued communication and trust between actors with a recent history of conflict. The provision of safe spaces to communicate and open lines of communication can be key to the success of these fragile peace agreements. Therefore, engagement in the mediation phase of peace negotiations is often accompanied by a commitment to remain involved throughout the process, including the post-conflict phase, in order to maintain relations built during active mediation (Spies, 2019 ${ }_{[2]}$ ). Increasingly, such commitment involves assistance in post-conflict reconstruction and development, and mediators use such commitments to shift incentives away from violence towards peaceful settlements (Spies, 2019[2]). This approach has technical and political implications for third-party diplomacy. It is crucial, therefore, that actors engaging in third-party diplomacy possess the skills to understand these implications, as well as the capacity to make the necessary long-term arrangements to assemble and co-ordinate efforts with other appropriate actors. This does not mean that diplomatic actors should implement development projects, but rather that they must possess a knowledge of development policies and practice.

Mediation should be seen as part of broader engagement to support peace. In many cases, it is conducted in conjunction with military efforts to provide the stability and security needed for fruitful peace negotiations (Forsberg, 2020[13]), development programmes and peacebuilding initiatives to re-establish social capital, including inter-communal trust and reconciliation (Cole, 2017 $7_{[18]}$. Security actor operations, development co-operation and peacebuilding efforts all have an impact on the dynamics of conflict and incentives for peace. Mediators use the leverage and dynamics of security and development engagement to craft peace agreements - and the implementation of such agreements requires sustained assistance, both financial and political. The actions and inaction of development, peacebuilding, and security actors can help reinforce a mediated solution or undermine its success (United Nations, 2017 $[73]$ ). It is therefore important to ensure that the full range of support to peace is mobilised and co-ordinated, seizing the opportunities for sustained peace that mediators facilitate.

\section{Official diplomacy may not be enough: "Track two" diplomacy and peacebuilding}

States and multilateral organisations are not the only bodies to engage in third-party diplomacy. Non-official parties such as individuals and non-governmental organisations increasingly intervene as third-party mediators in conflicts. Such track-two diplomacy is characterised by greater flexibility, and is more subtle, personal and free from the constraints of official policies and positions, and thus complementary to the mediation efforts of official actors (Böhmelt, 2010[4]). Track-two diplomatic actors engage primarily at the grassroots and middle-management level in an effort to influence underlying relationships and promote mutual understanding and acknowledgement of each other's concerns. This approach can then form the basis for official negotiations (Böhmelt, 2010[4]). In the 1990s, the peace process between Israel and the Palestinian authority commenced with informal discussions between Yair Hirschfeld, an Israeli academic, 
and Abu Alaa, an official in the Palestine Liberation Organization (PLO) mediated by Norwegian sociologist Terje Rød Larsen. The result was a "declaration of principles" between the two parties that established the framework for later mediation efforts (Ross, 2004[85]).

In most conflicts, the role of such engagement is as important as formal negotiations among political elites. Conflicts are disruptive and destructive. They break down social capital, entrench hostile attitudes between groups and spur fear among affected populations. Such attitudes and feelings are not "resolved" by political settlements; they require deeper, longer-term and personal engagement between the groups involved (Mac Ginty, 2014[86]). Often, formal negotiations are not even possible without prior engagement at lower levels focusing on the attitudes and feelings between such groups (Böhmelt, 2010[4]).

Track two diplomacy and peacebuilding are closely related. The international peacebuilding NGO Search for Common Ground engages in both Track II diplomacy efforts and localised peacebuilding efforts to create the conditions for political settlements and peace between the parties to conflict, and among populations (Search for Common Ground, 2019 $\left.{ }_{[87]}\right)$. Peacebuilding in Fragile Contexts (Marley, 2020[5]) examines these efforts, arguing that the international community needs to address and finance peace efforts that focus on societal factors, and not only political processes between elites. 


\section{Diplomats as enablers, leaders and communicators}

Diplomatic actors can be expected to assume a daunting array of tasks in fragile and conflict-affected contexts. Reflecting on the international response to the conflict in Kosovo in 1999, Sir Ivor Roberts observed that at all stages diplomacy was intense:

bilateral, multilateral, a peace conference, deployment of missions and the threat and eventual use of force,
coping with the humanitarian consequences... very difficult and contentious legal issues, producing successful
resolutions in the Security Council, respecting human rights, establishing a UN Protectorate, ensuring peace
through military deployment, delivering justice through the courts and political institutions, and ending with a
country moving towards full independence, albeit not universally recognised (Roberts, 2018, p. 34[88]).

All the tasks highlighted by Roberts showcase the immense value of diplomatic actors in fragile and conflict-affected contexts, not only as peacebuilders (discussed in Chapter 3), but also as facilitators of work across the nexus, leading country-level responses to fragility and communicating with a diverse network of actors.

This chapter examines some of the roles of diplomatic actors in fragile contexts and considers how they are changing. It opens with an analysis of diplomatic functionality in fragile contexts focusing on the ability of diplomatic actors to engage and connect a diverse range of national and sub-national actors. The second section shows how wide access to actors in fragile contexts frequently places diplomatic actors in positions to exercise public and discreet leadership on issues affecting peace. Acknowledging diplomatic reach and leadership potential in fragile contexts, the final section considers some emerging challenges and what they mean for diplomatic practice.

\section{How can diplomatic actors influence responses to fragility in fragile contexts?}

\section{Diplomatic actors can enable and facilitate networks across the nexus}

Official diplomats operating in fragile contexts have unique mobility that allows them to engage with actors across the triple nexus, including multiple official and non-official actors, political, security, and business leaders, civil society, and other individuals and groups. This access and appreciation of the local character of fragility, together with their official status - which combines legal authority, legitimacy, and power of influence - frequently places diplomatic actors in positions to assume convening or facilitating roles that link national and international actors together on issues of fragility. This can play out in a variety of different ways. For example, in 2019, the UK Foreign and Commonwealth Office launched a programme on political transition in Ethiopia that linked the inputs of UK government agencies and international and national NGOs on issues such as court monitoring, gender analysis, and support to defence and policing performance and leadership (Foreign \& Commonwealth Office, $2019_{[89]}$ ). The US Department of State funds a series of programmes aimed at developing women's leadership in countering terrorism and violent extremism in Afghanistan and Iraq by "building women's capacity to lead change in their communities, such as by enabling women leaders in police and civil society to engage local authorities on countering violent 
extremism (CVE) policy and local communities to identify and act upon early warning signs of terrorist radicalisation to violence" (US Dept. of State, 2020[90]).

Through the application of such programmes, diplomatic actors enhance their knowledge of political dynamics at different levels and develop valuable networks within fragile contexts. As a result, they are frequently best placed to be "nexus trilingual" with the ability to provide leadership and bring actors and partners together on a range of issues.

\section{Forms of diplomatic leadership in fragile contexts}

\section{Diplomatic leadership is a key enabler of coherent approaches in fragile contexts}

Through discreet engagement and public diplomacy, diplomatic actors can play different leadership roles in building consensus and networks. Whether by persuasion, normative pressure or the application of incentives, diplomatic actors can build positive dialogue with local political leaders as a means to encourage political will for the development of local strategies and programmes to address issues of fragility. Depending on the context, and the presence of conflict, this can also include the selective application - bilaterally or multilaterally - of conditionality and coercion.

For example, in Cambodia in 2017, the Swedish embassy in Phnom Penh responded to a governmentrequested Supreme Court decision to outlaw the main opposition party, publicly announcing that it was reviewing its engagement with Cambodia: "We will not initiate any new government-to-government development co-operation agreements, except in the areas of education and research [...] and would be unable to support decentralisation reform in its current form" (Chan Thul, 2017[91]). In 2020, responding to severe restrictions on democratic space, respect for human rights, freedom of speech and "the possibility for civil society and the media to operate freely", the Swedish government announced that it would phase out its bilateral strategy for Cambodia by July 2021 (Embassy of Sweden, 2020[92]).

As embedded representatives of states or international organisations, diplomatic actors can invest time in building relationships with official and non-official actors in fragile contexts. In spite of the speed and invasiveness of modern communications technology, the discretionary and confidential aspects of these interactions can be highly important for addressing issues of sensitivity, particularly when preparing the way for mediation or negotiations to prevent or conclude situations of conflict or violence (Roberts, 2018, p. $\left.15_{[88]}\right)$. The confidential aspect of such engagement by diplomatic actors with senior leadership in a fragile context also affords them the opportunity to give voice to issues of concern emerging from civil society and other groups. These interactions frequently form vital parts of peacebuilding processes. They can also facilitate the discussion of sensitive issues associated with humanitarian and development activities in circumstances where humanitarian and development actors' access to elites may be limited.

Diplomacy can do more in the "nexus", therefore, than just helping to secure humanitarian access or anchor development in national policies and plans. It can also play a role in preventing violations under International Humanitarian Law, highlight the need for protection of civilians and essential infrastructure, and maintain engagement on the importance of inclusive approaches to development. This style of engagement can also be valuable for building local awareness and leadership capacity - through training and socialisation with external and internal actors and groups - for more sustainable processes and outcomes.

Diplomatic actors frequently convene ad hoc contact groups or co-ordinating mechanisms to support and enable donor responses in fragile contexts. For example, in the Democratic Republic of the Congo (DRC), Swedish diplomats chair a Nexus Donor Group that brings donors and practitioners from the humanitarian and development pillars together to facilitate dialogue on their respective areas of competence. This ability of diplomats to engage independently with security actors, including the leadership of MONUSCO, allows 
a security perspective to be shared with humanitarian and development actors, thereby ensuring, at least to some extent, visibility and awareness across the triple nexus in an extremely fragile context. For peacebuilding processes, the extent to which these groups are aligned with local institutions and process matters for building trust among donors and partners, and enhancing the quality of local ownership of the process. Similarly, in many contexts, Resident Coordinators must combine "strategic, diplomatic and operational skills" in a low-profile manner to "help bridge gaps in perceptions and approaches within domestic leadership - whether state and national, civilian and military, between different line ministries, or between the state and civil society" (Center on International Cooperation, 2019, p. 72[93]).

\section{Diplomatic leadership in situations of crisis and conflict}

Observing the potential of diplomatic leadership, Cornelie Bjola noted that in pursuit of solutions to issues in a given situation, "discerning diplomats" have the flexibility to "take on a leadership role by providing a sense of direction for action, mobilising fellowship and managing tensions" (Bjola, 2015[94]). In the context of international crises, Bjola, identified three distinct profiles of diplomatic leaders: the maverick (risk taker), the congregator (or convenor) and the pragmatist (Bjola, 2015[94]). The actions associated with these profiles may not always be visible to the public eye, but they do speak to the importance of versatility and persuasion in diplomatic roles. Diplomatic actors can adapt the tools at their disposal to respond to aspects of a crisis. For example, in response to the COVID-19 crisis in Gambia, the EU Ambassador, working with a local municipality, was able to adapt an existing programme, the Youth Empowerment Programme (YEP), to set up a "GMD 1 million challenge to support young innovative entrepreneurs with smart and effective solutions to help address the challenges caused by COVID-19" (Africa Renewal, 2020[95]).

In many conflict situations, high-ranking UN diplomats acting as special envoys or representatives of the Secretary General lead and co-ordinate the UN presence in the country or region. These profiles are often more publicly apparent when applied to politicians in official or quasi-diplomatic roles (Box 4.1). 


\section{Box 4.1. Political leadership in diplomatic roles in fragile contexts}

It is usual practice in some contexts to appoint politicians to ambassadorial positions. The distinction between politicians and career diplomats matters. For issues of visibility, political credibility or personality, politicians can be assigned roles in fragile contexts that are diplomatic in nature and will almost always depend on diplomatic support. There are numerous examples, ranging from Sir Paddy Ashdown in Bosnia to George Mitchell in Northern Ireland, of politicians who have been appointed to administrative and diplomatic positions of influence in support of peace and development.

This role is distinct from that of visiting political leaders, which can be beneficial in a number of ways depending on the situation in a fragile context. The latter can bring visibility and momentum to peace, linking development support to political progress, and so on. External political leadership, applied at the right time on the basis of diplomatic groundwork, can be highly effective for seizing moments of opportunity, by engaging political and security elites to influence the direction of policy in a fragile context on a range of issues. For example, France's President Macron has been involved in dialogue with governments in the Sahel region, as well as other donors and partners, in order to co-ordinate and intensify peace and development efforts (Munshi, 2020[96]). In this way, politicians assuming leadership roles and positions (however temporary) can be important for building legitimacy and credibility for investment among DAC members in - and support for - peace in a fragile contexts.

Politicians in such roles can also add their voice to particular issues of fragility in a manner not available to diplomatic actors by virtue of their role. For example, political announcements from EU and UN special representatives (and occasionally heads of state) on progress through the stages of post-conflict recovery in Kosovo, frequently used strong rhetoric regarding progress on minority rights as a key condition for transition to the next phase of the process.

The African Union (AU) and the Regional Economic Communities (REC) make frequent use of politicians in their diplomatic engagement for peace and security, using their ability to mobilise highlevel political engagement to further peace on the continent. In $92 \%$ of cases where an African institution was in charge of mediation efforts during African coups between 2000 and 2014, the lead mediator was a serving or retired president of an African State (Nathan, 2017[97]). Through the Panel of the Wise, which currently comprises two former presidents and three former ministers, the AU also employs the skills of high-ranking politicians to conduct diplomacy and further peace and security across the continent (African Union Comission, 2018[98]). This ability to mobilise high-level political engagement for peace is a comparative advantage of the $\mathrm{AU}$, granting the organisation legitimacy, access, and leverage in its political engagement across the continent.

\section{Diplomats as communicators and enablers}

The leadership qualities and practices of diplomatic actors are further challenged by the increasing application of new technologies in fragile contexts. This section explores three forms of diplomacy wherein diplomats act as communicators and enablers: public diplomacy, digital diplomacy and data diplomacy.

\section{Public and digital diplomacy ${ }^{8}$ in fragile contexts}

There is no agreed definition of public diplomacy, but for diplomats it is generally understood to mean the use of their position and platform in a host context to project their government's position on a given policy in "an attempt to influence mass public opinion" (Roberts, 2018, p. $\left.27_{[88]}\right)$. Digital diplomacy serves the same purpose through the application of a variety of communications technologies. The development and 
proliferation of social media communications, including in fragile contexts, has transformed diplomatic practice for foreign ministries and diplomats. The importance of online platforms such as Facebook, Instagram, Twitter and various blogs "has substantially altered how we now practice and perceive the role (and power) of communication" in fragile contexts, including during times of political crisis (Cassidy, 2016[99]). Depending on the fragile context, this can be a highly contested (and often misleading) space where embassies, state, and non-state groups compete to shape public opinion.

Critically analysing this space is vital for informing policy, particularly in extremely fragile or conflict-affected contexts, in order to gain an understanding of the aims, rhetoric, approaches and ideology of different groups who apply digital means to influence local and international audiences. For example, recent research on rebel groups in the Sahel has shown how "weak or ineffective violent non-state rebels or terrorist groups can use media to give the appearance of strength and capability" (Bos, 2019, p. 1347[100]). Public diplomacy can also be extremely effective for mobilising communities and shaping public debate on issues of fragility. It can allow new voices to be heard and may be used to build legitimacy and ownership of peacebuilding processes. However, as technology evolves, DAC members must adapt quickly to recognise the potential of software engineering, big data and artificial intelligence for public and digital diplomacy in the fragile contexts of the future.

\section{Linking strategies on digital diplomacy to multitrack engagement with local actors can broaden and deepen the basis for peacebuilding in fragile contexts.}

The value of track two and multitrack diplomacy in fragile contexts is well established - notably, the potential to link activities, individuals, institutions and communities to build and sustain peace. Recognising the multidimensional and systemic character of fragility, the extended reach of track two and multitrack initiatives - which link government officials, business leaders, academics and educators, civil society, religious groups, financial institutions and the media - frequently places diplomatic actors in positions to build and connect networks for peace (Diamond and McDonald, 1996[101]). Diplomatic actors in fragile contexts often engage beyond the host state to other important stakeholders, including local civil society organisations, political groups, and the private sector. This approach is not exclusive to diplomacy in fragile contexts, but is perhaps more prominent and important in contexts where governance capacity and inclusiveness is restricted, as is the case in many fragile contexts.

As mentioned previously, horizontal inclusion of non-ruling political elites and the public in dialogue, decision-making, and political processes can serve to prevent war and sustain peace. Engaging diplomatically with such stakeholders, supporting them and, when relevant, giving them a voice in peace processes and broader political debates can be an effective means to prevent conflict and sustain peace. Linking strategies for public and digital diplomacy to multitrack initiatives addresses the need for concurrent visibility and discretion in conflict-sensitive situations.

Emphasising the importance of integrating conflict sensitivity for peacebuilding approaches, recent research has pointed to numerous instances of diplomats and other international actors utilising the tools at their disposal to support peace processes. Such examples include finance, capacity building, and political support in Myanmar, creating space for civic engagement in Syria, and creating platforms for dialogue and exchange of information in Zimbabwe (Palmiano Federer et al., 2019, p. 13[102]). Conversely, the often fragmented nature of multitrack engagement - with multiple actors operating simultaneously can increase complexity and undermine cohesion. Beyond the Tracks? Reflections on Multitrack Approaches to Peace Processes (Palmiano Federer et al., 2019 $\left.{ }_{[102]}\right)$ notes that:

In many cases, there is no "conductor" at all, with only informal co-ordination among national and international actors taking roles at different level of society ... participants highlighted the need for co-ordination among national and international peace practitioners to develop organically, with a multitrack approach in mind and based on the realities of the context. 


\section{Data diplomacy for fragile contexts can help establish baselines for evidence-based responses to issues of fragility}

New technologies and the proliferation of data are changing diplomatic practice in fragile contexts. Managing the collation and application of data in fragile contexts brings forth new opportunities and challenges. The "scope, volume and intensity of global data connectivity is expected to explode in the coming years" (Bjola, 2019 [103]), and fragile contexts will not be exempt. The basis of diplomatic convening power and leadership can be found in both the knowledge, perspective and experience of diplomats, and their relative capacity to influence, persuade, and exert pressure for change in fragile contexts. Increasingly it can also be found in their ability - most often through third parties such as NGOs or academics - to generate and redistribute data on issues of fragility.

For example, EU missions - through the Instrument contributing to Stability and Peace (IcSP) financing mechanism - frequently fund NGOs, specialist consultants and others to gather data on issues ranging from gender perception surveys and youth employment to security sector audits. The value of such data in fragile contexts is significant, since it can provide information and statistics for the analysis, evaluation and development of humanitarian, development and peace programmes, and in sufficient volume can constitute an evidence base for reform in fragile contexts. When shared with local governments and institutions, such data can also help to establish a baseline for informed decision making and local policy development. For example, data on human resources systems in the Gambian security sector, gathered by the International Security Sector Advisory Team (ISSAT) of the Geneva Centre for Security Sector Governance, and funded by the EU, was handed over to the Gambian authorities to inform their security sector reform process in 2019 (DCAF, 2019 $\left.{ }_{[104]}\right)$.

In spite of the acknowledged difficulties of gathering data in extremely fragile and conflict-affected contexts, the established trend for the development of new technologies and increased investment in data gathering is expected to continue (Desai and Forsberg, 2020[19]). The associated impact on diplomatic practice across all tracks is likely to be significant. Diplomatic actors must be prepared to respond to the management and ethical challenges associated with data diplomacy in fragile contexts. The potential for "machine-learning algorithms and intelligent assistants" to add value at speed to the analysis of issues affecting peace and fragility must be weighed and balanced against the further erosion of boundaries "between foreign and domestic affairs" (Bjola, 2019, p. 100 [103] $)$. Given the reach of digital diplomacy and increased access to data in fragile contexts, diplomatic actors will also need to balance local peacebuilding priorities with ethical questions regarding the potential of digital domestic diplomacy and the importance of not ceding digital and public space to "technological-based non-state actors who may seek to challenge notions of power and influence in fragile contexts" (Bjola, 2019, p. 100 $\left.{ }_{[103]}\right)$. This challenge extends to the ethical responsibility to generate, manage, and distribute data in fragile contexts. 


\section{References}

ACCORD (2014), Silencing the Guns, Owning the Future: Realising a Conflict-Free Africa, African Centre for the Constructive Resolution of Disputes, Durban, South Africa, www.peaceau.org/uploads/arusha-au-high-level-retreat-report-web.pdf.

ACLED (2020), "Call unanswered: A review of responses to the UN appeal for a global ceasefire", Armed Conflict Location \& Event Data Project, https://acleddata.com/2020/05/13/callunanswered-un-appeal.

Adjei, M. (2019), "Women's participation in peace processes: A review of literature", Journal of Peace Education, Vol. 16/2, pp. 133-154, http://dx.doi.org/10.1080/17400201.2019.1576515.

Africa Renewal (2020, 21 April), "EU, ITC, GCCI \& Kanifing Municipal Council launch Challenge Fund for young entrepreneurs to tackle COVID-19 socio-economic challenges", Africa Renewal, www.un.org/africarenewal/news/coronavirus/eu-itc-gcci-kanifing-municipal-council-launchchallenge-fund-young-entrepreneurs-tackle-covid.

African Union Comission (2018), "Panel of the Wise (PoW)", African Union Commission, www.peaceau.org/en/page/29-panel-of-the-wise-pow.

African Union Commission (2019), "Operationalization of AU Peace Fund on track ahead of 2020", African Union Commission, Bureau of the Chairperson, Addis Ababa, https://au.int/en/pressreleases/20191106/operationalization-au-peace-fund-track-ahead-2020.

African Union Commission (2015), African Peace and Security Architecture. APSA Roadmap 20162020, African Union Commission, Peace and Security Department, Addis Ababa, www.peaceau.org/uploads/2015-en-apsa-roadmap-final.pdf.

Beltrami, S. (2020), "Conflict and hunger — Looking back, looking forward", World Food Programme Insights, https://insight.wfp.org/conflict-and-hunger-looking-back-looking-forward8b482c42ff7e.

Bjola, C. (2019), "Public diplomacy in the digital age", The Hague Journal of Diplomacy, Vol. 14/1-2, pp. 83-101, https://doi.org/10.1163/1871191X-14011032.

Bjola, C. (2015), "Diplomatic leadership in times of international crisis: The maverick, the congregator and the pragmatist", The Hague Journal of Diplomacy, Vol. 10/1, pp. 4-9, http://dx.doi.org/10.1163/1871191X-12341300.

Böhmelt, T. (2010), "The effectiveness of tracks of diplomacy strategies in third-party interventions", [4 Journal of Peace Research, Vol. 47/2, pp. 167-178, http://dx.doi.org/10.1177/0022343309356488. 
Bos, M. (2019), "Rebel diplomacy and digital communication: piblic diplomacy in the Sahel", International Affairs, Vol. 95/6, pp. 1331-1348, http://dx.doi.org/10.1093/ia/iiz195.

Boutellis, A. (2020), "Will peacekeeping weather the crisis of multilateralism?", The Global Observatory, https://theglobalobservatory.org/2020/01/will-peacekeeping-weather-crisismultilateralism.

Cassidy, J. (2016), "Crafting strategic MFA communication policies during times of political crisis: a note to MFA policy makers", Global Affairs, Vol 2/3, pp. 331-343, http://dx.doi.org/10.1080/23340460.2016.1239377.

Center on International Cooperation (2019), The Triple Nexus in Practice:Toward a New Way of Working in Protracted and Repeated Crises, https://cic.nyu.edu/sites/default/files/triple-nexus-inpractice-brochure-december-2019-final.pdf.

Chan Thul, P. (2017, 21 November), "Sweden stops some new aid for Cambodia in protest over crackdown", Reuters, www.reuters.com/article/us-cambodia-politics/sweden-stops-some-newaid-for-cambodia-in-protest-over-crackdown-idUSKBN1DL18S.

Cole, B. (2017), Fostering Diplomatic-Defense-Development (3D) Cooperation in Responding to Complex Crises, United States Institute for Peace, Washington, DC, www.usip.org/publications/2017/12/fostering-diplomatic-defense-development-3d-cooperationresponding-complex.

Commission on Global Security, Justice \& Governance (2015), Confronting the crisis of multilateralism, The Hague Institute for Global Justice and the Stimson Center, https://www.stimson.org/wp-content/files/fileattachments/Commission on Global Security Justice\%20 Governance 0.pdf

Conseil fédéral (2018), Bons offices : bilan des démarches de facilitation et de médiation de la Suisse au niveau international [Good offices: Review of Switzerland's facilitation and mediation efforts at the international level], Bern, www.eda.admin.ch/dam/eda/fr/documents/aussenpolitik/menschenrechte-menschlichesicherheit/20190114-gute-dienste FR.pdf.

Council on Foreign Relations (2019), "Women's participation in peace processes", Council on Foreign Relations, Washington, DC, www.cfr.org/womens-participation-in-peace-processes.

DCAF (2019), Support to EU to Conduct Human Resource Assessment of The Gambian Security Sector, Geneva Centre for Security Sector Governance, Geneva, https://issat.dcaf.ch/Learn/SSR-in-Practice2/Countries-Regions/Gambia-The/Support-to-EU-toConduct-Human-Resource-Assessment-of-The-Gambian-Security-Sector (accessed 14 June 2020).

Desai, H. (2020), "Conflict prevention and fragility", OECD Development Cooperation Working Papers, OECD Publishing, Paris.

Desai, H. and E. Forsberg (2020), "The multidimensional fragility framework", OECD Development Cooperation Working Papers, OECD Publishing, Paris.

Diamond, L. and J. McDonald (1996), Multi-Track Diplomacy: A Systems Approach to Peace, Kumarian Press, West Hartford, CT. 
Diaz, P. and S. Tordjman (2012), Women's Participation in Peace Negotiations: Connections between Presence and Influence, UN Women, New York, NY, https://peaceoperationsreview.org/wpcontent/uploads/2015/11/womens_partcipation_peace.pdf.

Duursma, A. (2020), "African solutions to African challenges: The role of legitimacy in mediating civil wars in Africa", International Organization, Vol. 74/2, pp. 295-330, http://dx.doi.org/10.1017/s0020818320000041.

Economist, The (2020, 5 May), "How covid-19 gave peace a chance, and nobody took it", www.economist.com/international/2020/05/05/how-covid-19-gave-peace-a-chance-and-nobodytook-it.

EEAS (2020), "EU in the World", European External Action Service, https://eeas.europa.eu/headquarters/headquarters-homepage/area/geo en.

Embassy of Sweden (2020), Greater democracy focus in development cooperation with Cambodia, www.swedenabroad.se/en/embassies/cambodia-phnom-penh/current/news/greater-democracyfocus-in-development-cooperation-with-cambodia.

EU (2014), Regulation (EU) No 230/2014 of 11 March 2014, Official Journal of the European Union, Strasbourg, https://ec.europa.eu/fpi/sites/fpi/files/documents/140311 icsp reg 2302014 en.pdf..

FDFA (2020), "Mediation", Federal Department of Foreign Affairs, Bern, Switzerland, www.eda.admin.ch/eda/en/fdfa/foreign-policy/human-rights/peace/switzerland-s-goodoffices/facilitation-and-mediation.html.

FDFA (2020), "Peace policy", Federal Department of Foreign Affairs, Bern, Switzerland, www.eda.admin.ch/eda/en/fdfa/foreign-policy/human-rights/peace.html.

Felter, C. (2019), "The role of the International Criminal Court", Council on Foreign Relations, Washington, DC, www.cfr.org/backgrounder/role-international-criminal-court.

Foreign \& Commonwealth Office (2019), Towards a Political Transition in Ethopia Programme Summary, London, https://assets.publishing.service.gov.uk/government/uploads/system/uploads/attachment data/fil e/876120/Towards a Political Transition in Ethiopia Programme SummaryFY 19 20.odt.

Forsberg, E. (2020), "Security actors in fragile contexts", OECD Development Cooperation Working Papers, OECD Publishing, Paris.

Gates, R. (2020), Exercise of Power: American Failures, Successes, and a New Path Forward in the Post-Cold War World, Alfred A. Knopf, New York, NY, www.penguinrandomhouse.com/books/550375/exercise-of-power-by-robert-m-gates.

Gates, S., H. Mokleiv Nygård and E. Trappeniers (2016), "Conflict recurrence", Peace Research Institute of Oslo: Conflict Trends, Vol. 02/2016, www.prio.org/utility/DownloadFile.ashx?id=9\&type=publicationfile.

Global Challenges Foundation (2017), Global Governance Models in History, Global Challenges Foundation, Stockholm, HYPERLINK "https://globalchallenges.org/wp-content/uploads/GGmodels-in-history-EN.pdf" https://globalchallenges.org/wp-content/uploads/GG-models-inhistory-EN.pdf. 
Gonzalez, M. and C. Sherman (2020), "Anti-corruption mission in Honduras in precarious position", Associated Press, https://apnews.com/25b5cd60c7cbdc900df5cd3438c7727a.

Gowan, R. (2020, 16 June), "What's happened to the UN Secretary-General's COVID-19 ceasefire call?", International Crisis Group, www.crisisgroup.org/global/whats-happened-un-secretarygenerals-covid-19-ceasefire-call.

Gowan, R. (2019, 6 November), "Three troubling trends at the UN Security Council", International Crisis Group, www.crisisgroup.org/global/three-troubling-trends-un-security-council.

Gulrajani, N. et al. (2020), "DFID and FCO merger: our experts' views", Overseas Development Institute, www.odi.org/blogs/17077-dfid-and-fco-merger-our-experts-views.

Guterres, A. (2020), "To silence the guns, we must raise the voices for peace", United Nations, www.un.org/en/un-coronavirus-communications-team/update-secretary-general\%E2\%80\%99sappeal-global-ceasefire.

Hickey, S. (2015), "Inclusive institutions", GSDRC Professional Development Reading Pack, https://gsdrc.org/wp-content/uploads/2015/12/Inclusive-Institutions RP.pdf.

Hudson, N. (2005), "En-gendering UN peacekeeping operations", International Journal: Canada's Journal of Global Policy Analysis, Vol. 60/3, pp. 785-807, http://dx.doi.org/10.1177/002070200506000313.

ICC (2011), The Rome Statute of the International Criminal Court, International Criminal Court, Tha Hague, www.icc-cpi.int/resource-library/documents/rs-eng.pdf

İlgü Özler, Ş. (2018), "The Universal Declaration of Human Rights at seventy: Progress and challenges", Ethics \& International Affairs, Vol. 32/4, pp. 395-406, http://dx.doi.org/10.1017/s0892679418000588.

International Crisis Group (2019), "Saving the Stockholm Agreement and averting a regional conflagration in Yemen", International Crisis Group, www.crisisgroup.org/middle-east-northafrica/gulf-and-arabian-peninsula/yemen/203-saving-stockholm-agreement-and-avertingregional-conflagration-yemen.

Kioki, B. (2003), "The right of intervention under the African Union's Constitutive Act: From noninterference to non-intervention", International Review of the Red Cross, Vol. 85/852, www.icrc.org/en/doc/assets/files/other/irrc 852 kioko.pdf.

Lanz, D. (2011), "Active neutrality constructed: The development of Swiss peace policy since the end of the Cold War", paper presented at the 6th ECPR General Conference, University of Iceland, Reykjavik, 24-27 August 2011.

Lanz, D. and S. Mason (2012), "Switzerland's experiences in peace mediation", Mediation Support Project, Swisspeace, Bern, Switzerland, www.swisspeace.ch/fileadmin/user upload/Media/Publications/Journals Articles/LanzMason Switzerland-mediation 2012.pdf.

Leffler, M. (2011), "September 11 in retrospect: George W. Bush's grand strategy, reconsidered", Foreign Affairs, Vol. 90/5, pp. 33-44, www.foreignaffairs.com/articles/2011-08-19/september-11retrospect.

Lowy Institute (2019), "Global Diplomacy Index”, Lowy Institute, 
https://globaldiplomacyindex.lowyinstitute.org.

Lupel, A. (2019), "Two tasks to get past the crisis of multilateralism. blog post", Global Observatory, [2

05-08-2019, https://theglobalobservatory.org/2019/08/two-tasks-get-past-crisis-multilateralism.

Mac Ginty, R. (2014), "Everyday peace: Bottom-up and local agency in conflict-affected societies", Security Dialogue, Vol. 45/6, pp. 548-564, http://dx.doi.org/10.1177/0967010614550899.

Mapendere, J. (2005), "Track one and a half diplomacy and the complementarity of tracks", Culture of Peace Online Journal, Vol. 2(1), pp. 66-81, https://peacemaker.un.org/sites/peacemaker.un.org/files/TrackOneandaHalfDiplomacy Mapend ere.pdf.

Marley, J. and H. Desai (2020), "Fragility and the SDGs", OECD Decelopment Cooperation Working Papers, OECD Publishing, Paris.

Marley, J. (2020), "Peacebuilding in fragile contexts", OECD Development Cooperation Working Papers, OECD Publishing, Paris.

Maull, H. (2020), "SWP Comment: Mulitlateralism", Stiftung Wissenschaft und Politik - German Institute for International and Security Affairs, www.swp-berlin.org/10.18449/2020C09.

Mehrl, M. and T. Böhmelt (2020), "How mediator leadership transitions influence mediation effectiveness", Conflict Management and Peace Science, http://dx.doi.org/10.1177/0738894220916833.

Minister for Foreign Affairs Margot Wallström (2019), Statement of Government Policy, Government of Sweden, Stockholm, www.regeringen.se/49132e/globalassets/regeringen/dokument/utrikesdepartementet/utrikesdekl arationen2019 engelska.pdf.

Munshi, N. (2020, 9 June), "Victory remains elusive in France's drive to quell Sahel insurgency", Financial Times, www.ft.com/content/4bacede6-0f56-43e1-a285-771f0a11d86e.

Nathan, L. (2017), "A survey of mediation in African coups", African Peacebuilding Network Working Papers, http://ssrc-cdn1.s3.amazonaws.com/crmuploads/new publication 3/a-surveyof-mediation-in-african-coups.pdf.

NATO (1949), North Atlantic Treaty, North Atlantic Treaty Organization, Brussels, www.nato.int/cps/en/natolive/official_texts_17120.htm.

O'Reilly, M., A. Súilleabháin and T. Paffenholz (2015), Reimagining Peacemaking: Women's Roles in Peace Processes, International Peace Institute, New York, NY, www.ipinst.org/wpcontent/uploads/2015/06/IPI-E-pub-Reimagining-Peacemaking.pdf.

OAS (2020), "Mission to support the fight against corruption and impunity in Honduras: About the mission", Organization for American States, www.oas.org/en/spa/dsdsm/maccih/new/mision.asp.

OECD (2020), "COVID-19, crises and fragility", OECD Policy Responses to Coronavirus (COVID19), www.oecd.org/coronavirus/policy-responses/covid-19-crises-and-fragility-2f17a262.

OECD (2020), "What does "inclusive governance" mean?: Clarifying theory and practice", OECD Development Policy Papers, No. 27, OECD Publishing, Paris, 
https://dx.doi.org/10.1787/960f5a97-en.

OECD (2019), DAC Recommendation on the Humanitarian-Development-Peace Nexus, OECD Legal Instruments, OECD Publishing, Paris, https://legalinstruments.oecd.org/public/doc/643/643.en.pdf.

OECD (2018), "The Development Assistance Committee's Mandate", www.oecd.org/dac/thedevelopmentassistancecommitteesmandate.htm.

OECD (2017), "DAC High Level Communiqué: 31 October 2017", www.oecd.org/dac/DAC-HLM2017-Communique.pdf.

OECD (2017), "Gender equality and women's empowerment in fragile and conflict-affected situations : A review of donor support", OECD Development Policy Papers, No. 8, OECD Publishing, Paris, https://dx.doi.org/10.1787/b75a1229-en.

OECD (2011), Busan Partnership for Effective Development Cooperation, Fourth High Level Forum on Aid Effectiveness, Busan, Republic of Korea, 29 November -1 December 2011, www.oecd.org/dac/effectiveness/49650173.pdf.

Olsson, L. and J. Tejpar (eds.) (2009), Operational Effectiveness and UN Resolution 1325 Practices and Lessons from Afghanistan, Swedish Defence Research Agency, Stockholm, www.peacewomen.org/sites/default/files/1325 PracticeLessonsAfghanistan SDRA May2009 0 .pdf.

Palmiano Federer, J. et al. (2019), Beyond the Tracks? Reflections on Multitrack Approaches to Peace Processes, Centre for Humanitarian Dialogue, the Center for Security Studies ETH Zurich, Folke Bernadotte Academy and swisspeace. https://css.ethz.ch/content/dam/ethz/special-interest/gess/cis/center-for-securitiesstudies/pdfs/Mediation-Multi-Track-01-block.pdf.

Porter, E. (2003), "Women, political decision-making, and peace-building", Global Change, Peace \& Security, Vol. 15/3, pp. 245-262, http://dx.doi.org/10.1080/0951274032000124965.

Reid, L. (2015), "Finding a peace that lasts”, Journal of Conflict Resolution, Vol. 61/7, pp. 14011431, http://dx.doi.org/10.1177/0022002715611231.

Roberts, S. (2018), Satow's Diplomatic Practice, Oxford University Press, Oxford, UK.

Ross, D. (2004), The Missing Peace: The Inside Story of the Fight for Middle East Peace, Farrar, Straus and Giroux, New York, NY.

Schreiber, D. and S. Loudon (2020), "Fit for fragility", OECD Development Policy Papers, OECD Publishing, Paris.

Search for Common Ground (2019), Power to the Peacebuilders: 2018 Impact Report, Search for Common Ground, Washington, DC, Brussels, www.sfcg.org/wp-content/uploads/2019/06/2018Impact-Report-Power-to-the-Peacebuilders.pdf.

SIPRI (2020), "SIPRI Multilateral Peace Operations Database [database]", Stockholm International Peace Research Institute, https://www.sipri.org/databases/pko.

Spies, Y. (2019), Global South Perspectives on Diplomacy, Palgrave Macmillan, London 
Svensson, I. (2007), "Bargaining, bias and peace brokers: How rebels commit to peace", Journal of [1 Peace Research, Vol. 44/2, pp. 177-194, http://dx.doi.org/10.1177/0022343307075121.

Thomson, J. (2020), "The growth of feminist (?) foreign policy", E-International Relations, www.eir.info/pdf/81543.

United Nations (2020), Resolution 2532 (2020), United Nations Security Council, New York, NY.

United Nations (2020), "Sanctions", United Nations Security Council, New York, NY, www.un.org/securitycouncil/sanctions/information.

United Nations (2020), "Secretary-General calls for global ceasefire, citing war-ravaged health systems, populations most vulnerable to novel coronavirus", United Nations Secretary-General, New York, NY, www.un.org/press/en/2020/sgsm20018.doc.htm.

United Nations (2019), "Mr. Mirko Manzoni of Switzerland - Personal Envoy of the SecretaryGeneral for Mozambique", United Nations Secretary-General, New York, NY, www.un.org/sg/en/content/sg/personnel-appointments/2019-07-08/mr-mirko-manzoni-ofswitzerland-personal-envoy-of-the-secretary-general-for-mozambique.

United Nations (2019), "Speakers call for reinvigorated multilateralism, stronger diplomacy to address global crises, as General Assembly marks international day", United Nations General Assembly, New York, NY, www.un.org/press/en/2019/ga12140.doc.htm.

United Nations (2018), Declaration of Shared Commitments on UN Peacekeeping Operations, United Nations General Assembly, New York, NY, https://peacekeeping.un.org/sites/default/files/dpko-dfs-declaration-shared-commitmentsunpeacekeeping-1812605e.pdf.

United Nations (2018), Resolution 73/271, United Nations General Assembly, New York, NY, https://undocs.org/en/A/RES/73/271.

United Nations (2017), "United Nations activities in support of mediation”, United Nations Secretary General, New York, NY, https://peacemaker.un.org/sites/peacemaker.un.org/files/DPA\%20Report\%20REV9\%20ENG\%2 OWEB.PDF.

United Nations (2015), Transforming our world: the 2030 Agenda for Sustainable Development, United Nations General Assembly, New York, NY, www.un.org/ga/search/view doc.asp?symbol=A/RES/70/1\&Lang=E.

United Nations (2014), Global Governance and Global Rules for Development in the Post-2015 Era, UN Committee for Development Policy, New York, NY, www.un.org/en/development/desa/policy/cdp/cdp publications/2014cdppolicynote.pdf.

United Nations (2014), Resolution 2189, United Nations Security Council, New York, NY, http://unscr.com/en/resolutions/doc/2189. ] 8

.


www.un.org/en/ga/search/view doc.asp?symbol=S/RES/1325(2000).

United Nations (1992), An Agenda for Peace: Preventive Diplomacy, Peacemaking and Peacekeeping, United Nations, New York, NY, www.un.org/ruleoflaw/files/A_47_277.pdf.

United Nations (1961), Vienna Convention on Diplomatic Relations, United Nations, Vienna, https://legal.un.org/ilc/texts/instruments/english/conventions/9 1 1961.pdf.

United Nations (1945), UN Charter, United Nations, New York, NY, www.un.org/en/sections/uncharter/un-charter-full-text.

US Dept. of State (2020), U.S. Diplomatic Leadership in Support of Women, Peace, and Security, www.state.gov/u-s-diplomatic-leadership-in-support-of-women-peace-and-security.

USIP (2018), "What is UNSCR 1325? An explanation of the landmark resolution on women, peace and security", United States Institute of Peace, Washington, DC, www.usip.org/gender peacebuilding/about UNSCR 1325.

Vanheukelom, J. (2012), "Political conditionality in the EU's development cooperation - pointers for a broader debate", GREAT Insights, Vol. 1(2), https://ecdpm.org/great-insights/trade-andhuman-rights/political-conditionality-eus-dev-cooperation-broader-debate.

Wallensteen, P. and I. Svensson (2014), "Talking peace”, Journal of Peace Research, Vol. 51/2, pp. 315-327, http://dx.doi.org/10.1177/0022343313512223.

Whineray, D. (2020), "Lessons for Peacekeeping and Peacebuilding from Darfur", The Global Observatory, https://theglobalobservatory.org/2020/02/lessons-for-peacekeeping-peacebuildingfrom-darfur.

Woldemichael, S. (2020, 23 January), “Will the AU Peace and Security Council do better in 2020?”, Institute for Security Studies, https://issafrica.org/iss-today/will-the-au-peace-and-securitycouncil-do-better-in-2020.

Young-Powell, A. (2019, 18 December), "What happens when an aid department is folded?", devex, www.devex.com/news/what-happens-when-an-aid-department-is-folded-96262. 


\section{Annex A. List of multilateral political missions in 2020}

Table A. Multilateral political missions, 2020

\begin{tabular}{|c|c|c|}
\hline Mission & Organisation & Context \\
\hline BINUH: United Nations Integrated Office in Haiti, Port-au-Prince & UN & Haiti \\
\hline $\begin{array}{r}\text { CNMC: United Nations Support for the Cameroon-Nigeria Mixed Commission, } \\
\text { Dakar }\end{array}$ & UN & Cameroon \\
\hline UNAMA: United Nations Assistance Mission in Afghanistan, Kabul & UN & Afghanistan \\
\hline UNAMI: United Nations Assistance Mission for Iraq, Baghdad & UN & Iraq \\
\hline $\begin{array}{r}\text { UNIOGBIS: United Nations Integrated Peace-building Office in Guinea-Bissau, } \\
\text { Bissau }\end{array}$ & UN & Guinea-Bissau \\
\hline $\begin{array}{r}\text { UNMHA: United Nations Mission to Support the Hudaydah Agreement, } \\
\text { Hudaydah }\end{array}$ & UN & Yemen \\
\hline UNOAU: United Nations Office to the African Union, Addis Ababa & UN & $\mathrm{AU}$ \\
\hline UNOCA: United Nations Regional Office for Central Africa, Libreville & UN & Central Africa \\
\hline UNOWAS: United Nations Office for West Africa and the Sahel, Dakar & UN & Sahel and West Africa \\
\hline $\begin{array}{r}\text { UNRCCA: United Nations Regional Centre for Preventive Diplomacy for Central } \\
\text { Asia, Ashgabat }\end{array}$ & UN & Central Asia \\
\hline $\begin{array}{r}\text { UNSCO: Office of the United Nations Special Coordinator for the Middle East } \\
\text { Peace Process, Jerusalem }\end{array}$ & UN & $\begin{array}{r}\text { West Bank and Gaza } \\
\text { strip }\end{array}$ \\
\hline UNSCOL: Office of the United Nations Special Coordinator for Lebanon, Beirut & UN & Lebanon \\
\hline UNSOM: United Nations Assistance Mission in Somalia, Mogadishu & UN & Somalia \\
\hline UNSMIL: United Nations Support Mission in Libya, Tripoli & UN & Libya \\
\hline United Nations Verification Mission in Colombia, Bogota & UN & Colombia \\
\hline Personal Envoy of the Secretary-General for Bolivia & UN & Bolivia \\
\hline Personal Envoy of the Secretary-General for Mozambique & UN & Mozambique \\
\hline Personal Envoy of the Secretary-General for Western Sahara & UN & Western Sahara \\
\hline Special Adviser to the Secretary-General on Cyprus & UN & Cyprus \\
\hline Special Adviser to the Secretary-General on Sudan & UN & Sudan \\
\hline Special Envoy of the Secretary-General for Burundi & UN & Burundi \\
\hline Special Envoy of the Secretary-General on Myanmar & UN & Myanmar \\
\hline Special Envoy of the Secretary-General for Syria & UN & Syria \\
\hline Special Envoy of the Secretary-General to the Great Lakes Region & UN & Great Lakes \\
\hline Special Envoy of the Secretary-General for the Horn of Africa & UN & Horn of Africa \\
\hline $\begin{array}{r}\text { Special Envoy of the Secretary-General for the Implementation of Resolution } \\
1559\end{array}$ & UN & Israel \\
\hline Special Envoy of the Secretary-General for Yemen & UN & Yemen \\
\hline UNRGID: United Nations Representative to the Geneva International Discussions & UN & International Discussions \\
\hline OMIK: OSCE Mission in Kosovo & OSCE & Kosovo \\
\hline OSCE Centre in Ashgabat & OSCE & Turkmenistan \\
\hline OSCE Mission to Bosnia and Herzegovina & OSCE & Bosnia and Herzegovina \\
\hline OSCE Mission to Moldova & OSCE & Moldova \\
\hline OSCE Mission to Montenegro & OSCE & Montenegro \\
\hline OSCE Mission to Serbia & OSCE & Serbia \\
\hline OSCE Mission to Skopje & OSCE & North Macedonia \\
\hline
\end{tabular}




\begin{tabular}{|c|c|c|}
\hline OSCE Observer Mission at the Russian Checkpoints Gukovo and Donetsk & OSCE & $\begin{array}{r}\text { Russian } \\
\text { Federation/Ukraine }\end{array}$ \\
\hline $\begin{array}{r}\text { OSCE Personal Representative of the Chairperson-in-Office for the Conflict Dealt } \\
\text { with by the Minsk Conference }\end{array}$ & OSCE & Azerbaijan \\
\hline OSCE Presence in Albania & OSCE & Albania \\
\hline OSCE Programme Office in Nur-Sultan & OSCE & Kazakhstan \\
\hline OSCE Programme Office in Bishkek & OSCE & Kyrgyzstan \\
\hline OSCE Programme Office in Dushanbe & OSCE & Tajikistan \\
\hline OSCE Project Co-ordinator in Ukraine & OSCE & Ukraine \\
\hline OSCE Project Co-ordinator in Uzbekistan & OSCE & Uzbekistan \\
\hline OSCE Special Monitoring Mission to Ukraine & OSCE & Ukraine \\
\hline AU Observer Mission in Burundi & AU & Burundi \\
\hline MISAHEL: AU Mission for Mali and the Sahel & AU & Mali \\
\hline MISAC: AU Mission for the Central African Republic and Central Africa & AU & Central African Republic \\
\hline $\begin{array}{r}\text { CTSAMVM: Ceasefire and Transitional Security Arrangements } \\
\text { Monitoring and Verification Mechanism }\end{array}$ & IGAD & South Sudan \\
\hline EULEX Kosovo & EU & Kosovo \\
\hline EUBAM Moldova and Ukraine & EU & Moldova/Ukraine \\
\hline EUAM Ukraine & EU & Ukraine \\
\hline EUMM Georgia & EU & Georgia \\
\hline EUBAM Rafah & EU & $\begin{array}{r}\text { West Bank and Gaza } \\
\text { strip }\end{array}$ \\
\hline EUAM Iraq & EU & Iraq \\
\hline EUCAP Somalia & EU & Somalia \\
\hline EUCAP Sahel Mali & EU & Mali \\
\hline EUCAP Sahel Niger & EU & Niger \\
\hline EUBAM Libya & EU & Libya \\
\hline EUAM RCA & EU & Central African Republic \\
\hline MAPP/OEA: OAS Mission to Support the Peace Process in Colombia & OAS & Colombia \\
\hline
\end{tabular}

Note: The multilateral political missions all have different mandates, sizes and functions.

Source: This graph is produced based on the authors' calculations using the SIPRI (SIPRI, 2020[108]) Multilateral Peace Operations Database https://www.sipri.org/databases/pko and desk research on multilateral organisations' own reporting of their political country presence.

\section{Notes}

1 The 29 DAC member states maintain embassies; the EU maintains permanent delegations. Data on embassies from the 29 DAC member states are gathered from the Lowy Institute Global Diplomacy Index. Data on European Union Delegations are gathered from EEAS. General consulates, political support missions and other types of diplomatic missions that are not European Union Delegations or DAC member state resident embassies have been excluded.

${ }^{2}$ The West Bank and Gaza strip do not host any resident embassies and there is no EU delegation to the West Bank and Gaza strip. However, there are a number of other diplomatic missions oriented towards relations with Palestinian Authorities, including an EU support office, several consulates and other representative offices from a number of DAC members.

3 The Delegation of the European Union to Yemen has been temporarily relocated to Amman since September 2017, visiting Yemen on a regular basis. 
${ }^{4}$ The Delegation of the European Union to Syria has been temporarily relocated to Beirut, visiting Syria on a regular basis.

${ }^{5}$ Authors' calculations based on SIPRI multilateral peace operations data, as well as desk research on multilateral organisations' own reporting of political country presences.

${ }^{6}$ Peacemaking refers to immediate measures to address conflicts and usually involves diplomatic action to bring conflict parties to a negotiated settlement. Peacebuilding on the other hand is a complex, longterm process, creating conditions conducive for sustainable peace. Peacebuilding measures address core issues that affect the functioning of society and the state.

${ }^{7}$ A negotiated settlement is a formal agreement between warring parties, which addresses the disputed incompatibility, either by settling all or part of it. Data on negotiated settlements is collected from Duursma $\left(2020_{[41]}\right)$ where the variable is coded through combining data from the UCDP Peace Agreement dataset, UN Peacemaker, and the PA-X dataset, as well as secondary literature and news reports, to code whether a negotiated settlement is concluded in a given year

8 The terms public diplomacy, digital diplomacy and eDiplomacy are often used interchangeably. 



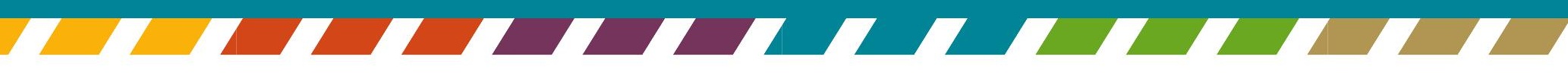

